2014

\title{
Norway's Socio-Legal Journey: A Qualitative Study of Boardroom Diversity Quotas
}

Aaron A. Dhir

Osgoode Hall Law School of York University, adhir@osgoode.yorku.ca

Follow this and additional works at: http:// digitalcommons.osgoode.yorku.ca/olsrps

\section{Recommended Citation}

Dhir, Aaron A., "Norway's Socio-Legal Journey: A Qualitative Study of Boardroom Diversity Quotas" (2014). Osgoode Legal Studies Research Paper Series. 21.

http://digitalcommons.osgoode.yorku.ca/olsrps/21 


\section{OSGOODE HALL LAW SCHOOL LEGAL STUDIES RESEARCH PAPER SERIES}

Research Paper No. 65

Vol. 10/ Issue. 15/ (2014)

\section{Norway's Socio-Legal Journey:} A Qualitative Study of Boardroom Diversity Quotas Dhir, A. (2015). Norway's Socio-Legal Journey: A Qualitative Study of Boardroom Diversity Quotas. Challenging Boardroom Homogeneity: Corporate Law, Governance, and Diversity. New York: Cambridge University Press. Forthcoming.

Aaron A. Dhir

\section{Editors:}

Editor-in-Chief: Carys J. Craig (Associate Dean of Research \& Institutional Relations and Associate Professor, Osgoode Hall Law School, York University, Toronto)

Production Editor: James Singh (Osgoode Hall Law School, York University, Toronto)

This paper can be downloaded free of charge from:

http://ssrn.com/abstract=2488153

Further information and a collection of publications from the Osgoode Hall Law School Legal Studies Research Paper Series can be found at:

http://papers.ssrn.com/sol/3/JELJOUR_Results.cfm?form_name=journalbrowse\&journal_id=722488 
Osgoode Legal Studies Research Paper No. 65

Vol. 10/ Issue. 15/ (2014)

\title{
Norway's Socio-Legal Journey: A Qualitative Study of Boardroom Diversity Quotas
}

Dhir, A. (2015). Norway's Socio-Legal Journey: A Qualitative Study of Boardroom Diversity Quotas. Challenging Boardroom Homogeneity: Corporate Law, Governance, and Diversity. New York: Cambridge University Press. Forthcoming.

Aaron A. Dhir

\begin{abstract}
:
This is chapter 4 of Challenging Boardroom Homogeneity: Corporate Law, Governance, and Diversity (Cambridge University Press, forthcoming in 2015). In this chapter I investigate the quota-based approach to achieving gender balance in corporate boardrooms. Quotas and related target-based measures for publicly traded firms are currently in place in a number of countries, including Iceland, Belgium, France, Italy, and Norway and are at different stages of consideration in other jurisdictions, including Canada, the European Union, and Germany.

I present findings from my qualitative, interview-based study of Norwegian corporate directors in order to provide empirical elucidation of how quota-based regimes operate in practice. The identity narratives of Norwegian board members offer particularly rich sources of insight, given that Norway was the first jurisdiction to pursue the quota path and thus has the most mature quota regime. While highly contentious when adopted, the Norwegian quota project unquestionably set the stage for subsequent legislative developments in other countries.

I delve into the lived experiences of Norwegian directors who gained appointments as a result of Norway's quota law, as well as those who held appointments before the law was enacted. Several questions frame my investigation. How have these individuals subjectively experienced, and made sense of, this intrusive form of regulation? How does legally required gender diversity affect their economic and institutional lives? And how has it shaped boardroom cultural dynamics and decision making, as well as the overall governance fabric of the board?

The forced repopulation of boards along gender lines has disturbed the traditional order of corporate governance systems, dislocating established hierarchies of power in key marketbased institutions. Norway represents the paradigmatic case of this disturbance and has set in motion a wave of corporate governance reform unlike any other. As such, it constitutes a fascinating and appropriate case study through which to consider the implications of quota regimes.
\end{abstract}




\section{Keywords:}

Corporate governance, corporate law, gender diversity, quotas, Norway, socio-legal research, qualitative research, semi-structured interviews

\section{Author(s):}

Aaron A. Dhir

Associate Professor of Law,

Osgoode Hall Law School

York University, Toronto

Visiting Professor of Law, Yale Law School (Fall Term, 2014)

E: adhir@osgoode.yorku.ca | aaron.dhir@yale.edu 
Not a final version. Final version forthcoming in Challenging Boardroom Homogeneity: Corporate Law, Governance, and Diversity (Cambridge University Press, 2015)

\section{CHAPTER 4}

\section{NORWAY'S SOCIO-LEGAL JOURNEY: A QUALITATIVE STUDY OF BOARDROOM DIVERSITY QUOTAS}

\section{Introduction}

In this chapter I present findings from my qualitative study of Norwegian corporate directors in order to provide some empirical elucidation of how quota-based regimes operate in practice. As I explain in more detail below, I interviewed male and female directors with a view to understanding their lived experiences both before and after the quota law came into effect. In the pages that follow, I explore in detail the rich set of responses elicited from my interviews. Some of my salient findings include:

- The societal acceptance of Norway's quota law has been to some degree a function of Norway's political culture and commitment to egalitarianism.

- Over time, support for the quota law amongst directors it affects has increased. Directors' views changed after they witnessed the law in action, experienced its effects, and came to the realization that change in the boardroom would require legal intervention, given the dynamics of in-group favoritism and closed social networks that thwart diversity.

- The dominant narrative my interviewees conveyed was that quota-induced gender diversity has positively affected boardroom work and firm governance. Generally, respondents emphasized the range of perspectives and experiences that women bring to the board, as well as the value of women's independence and outsider status. They also stressed women's greater propensity to engage in more rigorous deliberations, risk assessment, and monitoring.

- Most directors provided concrete examples of how, in their view, diversity had made a difference to Norwegian firms. These examples included a range of outcomes, from helping boards make difficult decisions (such as firing the CEO and handling crises), to having an impact in more functional areas (such as redesigning product marketing strategies).

- The presence of a critical mass of women matters to the achievement of diversity-related outcomes. And, in part because of the critical mass the quota law requires, women overall reported that they did not feel stigmatized. Though their stories are complex, the majority characterized the quota as a positive mechanism, one that facilitated their entry to the upper echelons of the corporation.

Together my findings suggest a case for a modified business rationale. Women's presence on the board, at a critical mass, can enhance boardroom decision making and the board's overall governance culture. These positive effects were achieved as a result of the quota law, which has also democratized access to a space previously unavailable to women. On these fronts, I judge the quota law a success to date. That said, the lived reality of the law also raises a number of difficult questions and unresolved issues regarding the value of board diversity and how best to achieve it. I explore my conclusions, and these complexities, in more detail in chapter 5 . Here, I focus instead on the particular experiences of directors that I uncover in my study.

In general, little is known about the operation of quota regimes around the world. In recent political science work on the spread of gender quotas in political life, scholars note the existing 
Not a final version. Final version forthcoming in Challenging Boardroom Homogeneity: Corporate Law, Governance, and Diversity (Cambridge University Press, 2015)

speculation on the likely impact of these measures. Advocates and detractors each opine that the mandates will alter the effectiveness and dynamics of political parties and institutions in some waywhether for better or worse. The speculation remains largely uncorroborated, however, and our knowledge is incomplete at best. ${ }^{1}$

We know even less about quotas in the corporate context, given that these laws have been enacted more recently. The study I present in this chapter seeks to remedy that gap. There are many unresolved questions in the debate over quotas as an ameliorative remedy. Given the range of sociopolitical contexts in which quotas have been implemented, and the diversity of individual experiences and organizational cultures within these contexts, it may be impossible to reach definitive or universal conclusions about quotas' effects. But we can at least deepen our understanding through empirical investigation of the quota experiences already initiated, so that analysis, rather than conjecture, informs the debate.

In this part of my study, I move past the numerical impact quotas have had on corporate boards to probe more deeply into their actual meaning and effects. Using a qualitative methodology, with a phenomenological lens, ${ }^{2}$ I seek to replace speculation with an account of real-life boardroom reality. Returning to the themes laid out in chapter 1, I am interested in exploring corporate governance's human elements ${ }^{3}$ and am particularly interested in illuminating law's role in transforming the board's "decision-making culture." ${ }^{4}$ Before doing so, I place the Norwegian quota law in socio-political context and briefly explain the design of my research. ${ }^{5}$

\section{Norway's quota law in context}

The Nordic corporate governance structure "lies between" the unitary (Anglo-Saxon) and dual (continental European) systems ${ }^{6}$ and has been characterized as a "one and a half-string system." ${ }^{7}$ Norwegian corporate law specifies that the board of directors has both management ${ }^{8}$ and supervisory functions. ${ }^{9}$ Daily management responsibilities are statutorily assigned to a "general manager" - in other

\footnotetext{
${ }^{1}$ Mona Lena Krook \& Pär Zetterberg, "Electoral Quotas and Political Representation: Comparative Perspectives" (2014) 35:1 Int'l Pol Sci Rev 3 at 4.

${ }^{2}$ See generally Clark Moustakas, Phenomenological Research Methods (Thousand Oaks, Cal: SAGE, 1994).

${ }^{3}$ Morten Huse, Boards, Governance and Value Creation (Cambridge, UK: Cambridge University Press, 2007) at 209.

${ }^{4}$ Ibid at 208.

${ }^{5}$ For a review of previous studies on the Norwegian quota law's effects on corporate governance, see Morten Huse, "The 'Golden Skirts': Lessons from Norway about Women on Corporate Boards of Directors" in Stefan Gröschl \& Junko Takagi, eds, Diversity Quotas, Diverse Perspectives: The Case of Gender (Farnham, England: Gower, 2012) 11 at 15-16 (characterized by the author as "few").

${ }^{6}$ Beate Sjåfjell \& Cecilie Kjelland, "Norway: Corporate Governance on the Outskirts of the EU" in Andreas M Fleckner \& Klaus J Hopt, eds, Comparative Corporate Governance: A Functional and International Analysis (New York: Cambridge University Press, 2013) 702 at 713-14. See also Danish Corporate Governance Committee et al, "Corporate Governance in the Nordic Countries" (April 2009) at 8, online: Iceland Chamber of Commerce $<$ www.vi.is/files/Nordic\%20CG\%20-\%20web 1472238902.pdf>.

7 Inger Marie Hagen, "Employee-Elected Directors on Company Boards: Stakeholder Representatives or the Voice of Labour" in Roger Blanpain et al, eds, Rethinking Corporate Governance: From Shareholder Value to Stakeholder Value (Alphen aan den Rijn, the Netherlands: Kluwer, 2011) 121 at 128.

${ }^{8}$ Norwegian Public Limited Liability Companies Act, Del K:1, no 45 of 13 June 1997, s 6-12(1) [translated by the law firm Schjødt] [Norway] ("The management of the company pertains to the board of directors. The board of directors shall ensure a proper organization of the business of the company.").

${ }^{9} \mathrm{Ibid}$, s 6-13(1) ("The board of directors shall supervise the day-to-day management and the company's business in general.").
} 
Not a final version. Final version forthcoming in Challenging Boardroom Homogeneity: Corporate Law, Governance, and Diversity (Cambridge University Press, 2015)

words, a CEO-who must abide by the board's directions. ${ }^{10}$ The general manager typically appoints the remainder of the high-level management team. ${ }^{11}$

Companies with two hundred or more employees must have an additional supervisory body called a corporate assembly, ${ }^{12}$ unless the firm and the majority of its employees consent to omitting it. ${ }^{13}$ The corporate assembly must have twelve or more members. ${ }^{14}$ It is this optional corporate assembly that comprises the "one-half" element of Norway's board structure; its tasks include electing the board's chair and its directors ${ }^{15}$ and supervising the CEO and the board, ${ }^{16}$ which, as noted, itself also has both supervisory and management duties.

The current iteration of the Norwegian quota law (described in chapter 3) has a rather complicated and technical past. Norway's formal legislative journey began with measures passed in 2003, which applied a quota to state-owned and municipal companies and to companies incorporated by special legislation. ${ }^{17}$ Soon after, Norway took steps to extend these measures to public limited liability companies, known in Norway as allmennaksjeselskap or "ASA" firms. Private limited liability companies, known as aksjeselskap, or "AS" firms, do not fall under the quota regime's umbrella.

The law vis-à-vis ASA firms evolved in three phases. Prior to January 1, 2004, Norwegian public companies were not subject to any form of quota-based regulation. In phase 1 (January 1, 2004December 31, 2005), under a government-industry agreement, compliance with the quota law was voluntary. During this period, the government gave firms the opportunity to address gender imbalances within their governance structures without formal state intervention. However, a Statistics Norway study revealed that by the prescribed deadline during phase 1 (July 1, 2005), only 68 of 519 (13.1 percent) of ASA companies had reached the intended levels of representation. By that date, approximately 16 percent of directors were female, much lower than the government's expectation. ${ }^{18}$

10 Ibid, s 6-14(1) ("The general manager is in charge of the day-to-day management of the company's business and shall comply with the guidelines and instructions issued by the board of directors.").

${ }^{11}$ Sjåfjell \& Kjelland, supra note 6 at 714.

${ }^{12}$ Norway, supra note 8, s 6-35(1). Subsection 6-40(1) provides that companies' articles of association can establish an assembly even if not required under the statute.

13 Ibid, s 6-35(2). Additionally, companies in the financial, shipping, media, and extractive sectors are not subject to this requirement. See $\varnothing$ yvind Bøhren \& R $\varnothing$ ystein Strøm, "The Value-Creating Board: Theory and Evidence" (2005) at 15, online: BI Norwegian Business School

<http://web.bi.no/forskning/papers.nsf/0/b1b4fc5811a7c54cc125709900418106/\$FILE/2005-08-bohrenstrom.pdf>.

${ }^{14}$ Norway, supra note 8, s 6-35(1). If the assembly has more than twelve members, the total number of members must be divisible by three. Two-thirds of the assembly is elected by the general shareholders' meeting and the remaining one-third by the employees from amongst themselves. See subsections 6-35(1), (3), and (4), respectively.

${ }^{15}$ Ibid, s 6-37(1).

${ }^{16}$ Ibid, s 6-37(2).

${ }^{17}$ Act of 19 December 2003 No 120, Part XII, para 1; Norway, Royal Ministry of Children and Family Affairs, "Followup to the Package Meeting of 9 to 10 November 2005 Regarding Representation of Both Sexes on Company Boards" at 3, online:

<http://www.regjeringen.no/upload/BLD/Engelsk/Balanced\%20gender\%20representation\%20on\%20company\%20 boards/Svarbrev til ESA 19122005.pdf>.

${ }_{18}$ Norwegian Mission to the EU, “Norway's Mixed Gender Boardrooms” (8 June 2009), online: <http://www.eunorway.org/news/gender rep boardrooms/>. 
Not a final version. Final version forthcoming in Challenging Boardroom Homogeneity: Corporate Law, Governance, and Diversity (Cambridge University Press, 2015)

In response, the Norwegian government made quotas compulsory beginning on January 1, 2006. In phase 2, from January 1, 2006 to December 31, 2007, all existing ASA firms were provided a two-year transitional period to reach the representation levels the quota law required or face potential dissolution. All newly incorporated firms, however, had to demonstrate immediate compliance with the quota. Finally, since January 1, 2008, all firms have been required to comply with the quota (phase 3 ). Notably, all corporations have achieved conformity. ${ }^{19}$

Others have canvassed the details of the quota law's political advancement and the ensuing public deliberations. ${ }^{20}$ At a general level though, the seeds of the law were initially planted in 1999, during discussions pertaining to the reform of Norway's gender equality legislation. ${ }^{21}$ During the consultative process, the location of the proposed quota shifted from the Gender Equality Act to Norway's corporate law. ${ }^{22}$ Interestingly, while the rationale of gender egalitarianism was certainly present in the political discourse surrounding the law, it appears that the primary discourse centered on firm competitiveness. ${ }^{23}$ Considerable credit has been given to the leadership of Ansgar Gabrielsen, the former minister of trade and industry of Norway's center-right Conservative Party, particularly in the final chapter of the quota's legislative journey. ${ }^{24}$ According to the story, Gabrielsen telephoned a reporter with the country's most-read news outlet and requested a meeting. During the interview, which occurred immediately prior to the coalition government's closing debate on the quota law, Gabrielsen revealed his abhorrence for the influence and control that men exercised in Norwegian corporate culture. Apparently, Gabrielsen elected not to confer with any political colleagues prior to the interview. His comments marked a turning point, effectively muting the Party members who were most opposed to the law. ${ }^{25}$ In the interviews I conducted with Norwegian directors, a number of participants stressed the importance of this moment, one characterizing it as a bold "coup":

$[\mathrm{H}] \mathrm{e}$ knew he would get heavy hits, because that's the most unusual thing to do as a minister . . . at least [as] the minister of trade in a conservative coalition. . . . And him being a right-wing conservative. But that's how it all started. . . . [A]nd then the battle began, but . . . the whole government had to stand behind him! . . That's the most amazing story you will ever hear. And it needs to go into your book (laughing). ${ }^{26}$

\footnotetext{
${ }^{19}$ Anne Kjølseth Ekerholt \& Carmen Di Marino, "Norway" in Paul Hastings LLP, "Breaking the Glass Ceiling: Women in the Boardroom", 3d ed (2013), 94 at 96, online: <http://www.paulhastings.com/genderparity/pdf/Gender Parity Report.pdf>.

${ }^{20}$ See e.g. Mari Teigen, "Gender Quotas for Corporate Boards in Norway: Innovative Gender Equality Policy" in Colette Fagan, Maria C González Menéndez \& Silvia Gómez Ansón, eds, Women on Corporate Boards and in Top Management: European Trends and Policy (Basingstoke, England: Palgrave Macmillan, 2012) 70 at 78-82.

${ }^{21}$ Ibid at 78.

22 Ibid at 78-79.

${ }^{23}$ Hilde Bjørkhaug \& Siri Øysleb $\varnothing$ Sørensen, “Feminism without Gender? Arguments for Gender Quotas on Corporate Boards in Norway" in Fredrik Engelstad \& Mari Teigen, eds, Firms, Boards and Gender Quotas: Comparative Perspectives, vol 29 (Bingley, UK: Emerald, Comparative Social Research, 2012) 185 at 198-99.

${ }^{24}$ Teigen, supra note 20 at 79.

25 Ibid; Morten Huse, "The Political Process Behind the Gender Balance Law" in Silke Machold et al, eds, Getting Women on to Corporate Boards: A Snowball Starting in Norway (Cheltenham, UK: Edward Elgar, 2013) 9 at 11-12.

${ }^{26}$ Interviewee 8, Transcript, at 14-15.
} 
Not a final version. Final version forthcoming in Challenging Boardroom Homogeneity: Corporate Law, Governance, and Diversity (Cambridge University Press, 2015)

Gabrielsen's own reflections underscore the salience of his chosen course of action: "If I had told them before, the initiative would have been killed by one committee after another. . . I had to employ terrorist tactics. Sometimes you have to create an earthquake, a tsunami, to get things to change."27

\section{Research design}

\section{A. Access and trust}

As discussed in chapter 1 , in order to understand quota-based corporate governance regulation, it is necessary to explore the lived realities of the board members it directly affects. How have they experienced this interventionist form of regulation? How does legally required gender diversity affect their economic and institutional lives? Conducting this exploration, however, is very challenging. Boards of directors are often small, socially similar, and closely bonded units. ${ }^{28}$ They are elite decision-making entities that engage with highly sensitive topics. ${ }^{29}$ Their members lead busy professional lives. It is not surprising, then, that boards are notoriously difficult for outsiders to access for academic investigation ${ }^{30}$ and have been analogized to "black boxes" ${ }^{31}$ and "fortresses." ${ }^{32}$ Directors may be hesitant to offer their rare spare minutes and insights to those who have not established a preexisting relationship of trustespecially with regard to delicate issues such as diversity. ${ }^{33}$

Mindful of these difficulties, I employed a range of strategies to develop a sample population of Norwegian directors whom I could interview. Relying on professional contacts, I first established a small initial set of interview participants. I then utilized a referral technique known as snowball sampling to identify additional interviewees. After conducting each initial interview, I asked the participant if she or he would be willing to identify or reach out to a director colleague who might be interested in speaking with me. This nonprobability sampling method is especially helpful in studies where it is challenging to access population members, ${ }^{34}$ such as sex workers, gang members, the homeless, ${ }^{35}$ and professional elites such as high-ranking members of government and executives of private institutions. ${ }^{36}$ Researchers studying corporate board diversity have used it to great effect. ${ }^{37}$ I provide additional detail on the strategies I used in the appendix.

${ }^{27}$ Christine Toomey, "Quotas for Women on the Board: Do They Work?", The Sunday Times (8 June 2008), online: <http://www.thesundaytimes.co.uk/sto/style/article96924.ece>.

${ }^{28}$ Rakesh Khurana \& Katharina Pick, "The Social Nature of Boards" (2005) 70:4 Brook L Rev 1259 at 1266.

29 Richard Leblanc \& Mark S Schwartz, "The Black Box of Board Process: Gaining Access to a Difficult Subject" (2007) 15:5 Corp Governance: Int'| Rev 843 at 847, 850.

30 lbid at 846 .

${ }^{31}$ David SR Leighton \& Donald H Thain, Making Boards Work: What Directors Must Do To Make Canadian Boards Effective (Toronto: McGraw-Hill Ryerson, 1997) at xv; Catherine M Daily, Dan R Dalton \& Albert A Cannella, Jr, "Corporate Governance: Decades of Dialogue and Data" (2003) 28:3 Academy Mgmt Rev 371 at 379.

32 Ibid at 378.

33 Lissa L Broome, John M Conley \& Kimberly D Krawiec, “Dangerous Categories: Narratives of Corporate Board Diversity" (2011) 89:3 NCL Rev 759 at 769 [Broome, Conley \& Krawiec, "Dangerous Categories"].

${ }^{34}$ Colin Robson, Real World Research, 3d ed (Padstow, Great Britain: John Wiley, 2011) at 274-76.

35 Russell K Schutt, Investigating the Social World: The Process and Practice of Research, 7th ed (Thousand Oaks, Cal: SAGE, 2012) at 158.

${ }^{36}$ Robert Mikecz, "Interviewing Elites: Addressing Methodological Issues" (2012) 18:6 Qualitative Inquiry 482 at 491.

${ }^{37}$ See e.g. Broome, Conley \& Krawiec, "Dangerous Categories", supra note 33 at 768-69. 
Not a final version. Final version forthcoming in Challenging Boardroom Homogeneity: Corporate Law, Governance, and Diversity (Cambridge University Press, 2015)

\section{B. Profile of the sample population}

My final sample consisted of twenty-three in-depth, semi-structured interviews with directors of Norwegian corporate boards. ${ }^{38}$ Of the participants, twenty-one were Norwegian, one was Swedish, and one was a non-Scandinavian citizen who had been resident in Norway for many years. All interviewees had direct or indirect experience with Norway's corporate "quotations" - what North Americans would refer to as "quotas." ${ }^{39}$ The vast majority (95.6 percent) had first-hand experience with the quota: at the time of the interview, twenty-two directors were either sitting members of ASA company boards subject to the mandatory law ("quota boards") or had previously sat on a quota board. One director did not have past or present experience sitting on a quota board, but explained that the law nonetheless influenced some of her nonquota (private company) appointments, in the sense that she believed she obtained the positions as an indirect result of the law. Overall, the sample includes directors who held appointments during each of the developmental phases discussed above. Nine respondents (39.1 percent) sat on ASA boards prior to the beginning of the quota law period. The breadth of experience in my sample therefore provided me not only with rich data regarding the current regulatory climate, but also with valuable points of comparison between this climate and the period prior to the law's enactment. Table 4.1 presents a breakdown of the respondents' overall board experience during each phase, disaggregated by gender. Table 4.2, also disaggregated by gender, provides information on when participants received their first ASA appointment.

Table 4.1 - Sample's overall ASA board experience by quota phase

\begin{tabular}{|l|l|l|l|l|}
\hline & $\begin{array}{l}\text { Prequota: } \\
\text { Experience with } \\
\text { ASA board(s) prior } \\
\text { to quota law (pre- } \\
\text { January 1, 2004) }\end{array}$ & $\begin{array}{l}\text { Phase 1: } \\
\text { Experience with ASA } \\
\text { board(s) during } \\
\text { voluntary period } \\
\text { (January 1, 2004- } \\
\text { December 31, 2005) }\end{array}$ & $\begin{array}{l}\text { Phase 2: } \\
\text { Experience with ASA } \\
\text { board(s) during } \\
\text { transitional period } \\
\text { (January 1, 2006- } \\
\text { December 31, 2007) }\end{array}$ & $\begin{array}{l}\text { Phase 3: } \\
\text { Experience with ASA } \\
\text { board(s) during } \\
\text { mandatory period } \\
\text { (January 1, 2008-date } \\
\text { of interview) }\end{array}$ \\
\hline Female & 4 & 6 & 13 & 15 \\
\hline Male & 5 & 5 & 6 & 7 \\
\hline Aggregate & $9(39.1 \%)$ & $11(47.8 \%)$ & $19(82.6 \%)$ & $22(95.7 \%)$ \\
\hline
\end{tabular}

Table 4.2 - Sample's first ASA board appointment by quota phase

\begin{tabular}{|c|c|c|c|c|}
\hline & $\begin{array}{l}\text { Prequota: } \\
\text { First appointed to } \\
\text { ASA board(s) prior } \\
\text { to quota law (pre- } \\
\text { January } 1,2004)\end{array}$ & $\begin{array}{l}\text { Phase 1: } \\
\text { First appointed to ASA } \\
\text { board(s) during } \\
\text { voluntary period } \\
\text { (January 1, 2004- } \\
\text { December } 31,2005 \text { ) }\end{array}$ & $\begin{array}{l}\text { Phase 2: } \\
\text { First appointed to ASA } \\
\text { board(s) during } \\
\text { transitional period } \\
\text { (January 1, 2006- } \\
\text { December } 31,2007 \text { ) }\end{array}$ & $\begin{array}{l}\text { Phase 3: } \\
\text { First appointed to ASA } \\
\text { board(s) during } \\
\text { mandatory period } \\
\text { (January 1, 2008-date } \\
\text { of interview) }\end{array}$ \\
\hline Female & 4 & 3 & 6 & 2 \\
\hline Male & 5 & 1 & 0 & 2 \\
\hline Aggregate & $9(39.1 \%)$ & $4(17.4 \%)$ & $6(26.1 \%)$ & $4(17.4 \%)$ \\
\hline
\end{tabular}

${ }^{38}$ Ruth Sealy, “Changing Perceptions of Meritocracy in Senior Women's Careers” (2010) 25:3 Gender Mgmt: Int'I J 184.

39 Kate Sweetman, “Norway's Boards: Two Years Later, What Difference Do Women Make?”, Fast Company (13 July 2009), online: <www.fastcompany.com/1308538/norway\%E2\%80\%99s-boards-two-years-later-whatdifference-do-women-make>. 
Not a final version. Final version forthcoming in Challenging Boardroom Homogeneity: Corporate Law, Governance, and Diversity (Cambridge University Press, 2015)

The sample reported approximately ninety-five quota board appointments in total (current and prior), at more than seventy respective corporations. ${ }^{40}$ These figures reflect the fact that some respondents served on the same boards and some held multiple directorships. Their positions were in a wide range of commercial industries, including: finance and insurance; resource extraction; property and real estate; shipping; agriculture; technology; automotive; media and communications; education; healthcare; human resources; hospitality; pulp and paper; and retail. The sample possesses board experience on small, medium, and large capitalization corporations. Some of Norway's most prominent companies are represented, including firms listed in the Forbes Global 2000. My sample also had varied levels of professional experience: The most senior director's public company board service spanned twenty years, while the most junior director had sat on such boards for two years. The majority of interviewees (fifteen, or 65.2 percent) had either CEO or senior management experience, though a significant minority (eight, or 34.8 percent) did not. In addition to their corporate governance experience, the respondents brought a wealth of professional backgrounds to the boardroom, including: investment banking; consulting; law; line management in a range of industries; communications; engineering; politics; private equity; and financial analysis.

Fifteen interviewees (65.2 percent) were women and eight (34.8 percent) were men. All were White and ranged in age from thirty-eight to seventy-two years, the average age being fifty-two. The average age of the female interviewees was forty-nine and that of the men was fifty-eight. Table 4.3 illustrates the age profile of the sample, disaggregated by gender. It was a very well-educated group in terms of the highest degrees attained. Fifteen (65.2 percent) reported having earned a graduate degree, such a Masters of Business Administration or its equivalent, another graduate-level business degree, a Master of Laws, or a Masters in another field such as Arts, Science, Economics, and Engineering. Three interviewees (13 percent) graduated from law school, and four (17.4 percent) held bachelor's degrees. Only one (4.3 percent) did not possess a university degree, though this respondent completed some university-level courses. The majority of interviewees (approximately 70 percent) reported having a spouse or partner and/or children.

Table 4.3 - Profile of sample by age and gender

\begin{tabular}{|l|l|l|l|}
\hline & Female & Male & Aggregate \\
\hline Average Age & 49.1 & 58.8 & 52.4 \\
\hline Median Age & 49 & 57.5 & 50 \\
\hline Minimum Age & 38 & 49 & 38 \\
\hline Maximum Age & 61 & 72 & 72 \\
\hline
\end{tabular}

\section{Data collection, analysis, and limitations}

I approached each meeting with a flexible interview guide that set out particular questions and key themes. ${ }^{41}$ I first asked respondents to discuss their individual and professional backgrounds. We then discussed the corporate governance practices and policies of the boards on which they have served; their experiences with, and views on, board diversity; and their experiences with, and views on, the Norwegian quota regime in particular. We focused considerably on diversification's effect, if any, on boardroom cultural dynamics, governance, and decision making, and on the lives of female directors. The conversations frequently took a direction of their own, as together we unearthed numerous

\footnotetext{
40 This figure excludes one outlier director, who reported sitting on an inordinate number of boards due to structural issues associated with that director's board positions.

${ }^{41}$ Alan Bryman, Social Research Methods, 3d ed (New York: Oxford University Press, 2008) at 442.
} 
Not a final version. Final version forthcoming in Challenging Boardroom Homogeneity: Corporate Law, Governance, and Diversity (Cambridge University Press, 2015)

relevant issues. Mindful of the extensive conjecture regarding the effects of board diversity quotas, I strived to draw out the respondents' narratives in a manner "that allowed them to express themselves in their own words and as "knowers' of their own life stories." ${ }^{42}$ । sought to "uncover, rather than presuppose" the interview participants' subjective truths. ${ }^{43}$

In qualitative research, phenomenological investigations center on "the meaning for several individuals of their lived experiences of a concept or a phenomenon." ${ }^{44}$ As noted, my primary objective was to understand Norwegian directors' lived experiences with the corporate quota law and the phenomenon of legally mandated gender balance, with a view towards informing current international policy debates. As such, a phenomenological lens was an ideal fit for the task at hand, and I used phenomenological research methods to analyze the narrative data. In the appendix, I discuss the data collection and analysis processes in more detail.

As Johnson observes, there is no consensus on the optimal number of interviewees for a qualitative study. ${ }^{45}$ Much depends on the questions under consideration and the investigator's goals. ${ }^{46}$ That said, Creswell notes the literature's recommendation that phenomenological studies include "from 5 to 25 individuals who have all experienced the phenomenon." ${ }^{\prime 47}$ This study's sample size (again, twenty-three) fits squarely within this suggestion. However, given the relatively small population, and the qualitative nature of the study, I do not suggest any statistically significant generalizations. This is by no means a comprehensive investigation of the experiences of Norwegian corporate directors, and the sample was not randomly selected-both are potential limitations.

That said, my sample enables an expansive and richly textured account of governance diversity in Norwegian firms for several reasons: (1) its significant experience on different boards and at different levels of the governance hierarchy; (2) its experience with the quota law at all stages of its development; (3) its representation of a wide range of commercial industries and all levels of market capitalization; (4) its variance in age and experience levels; and (5) mindful of the self-described limitations of previous studies, its inclusion of both men and women, ${ }^{48}$ which provides perspectives from both sides of the gender coin.

\footnotetext{
${ }^{42}$ Susan Thomson, "The Darker Side of Transitional Justice: The Power Dynamics Behind Rwanda's Gacaca Courts" (2011) 81:3 Africa 373 at 376.

43 Ibid.

${ }^{44}$ John W Creswell, Qualitative Inquiry \& Research Design: Choosing Among Five Approaches, 3d ed (Thousand Oaks, Cal: SAGE, 2013) at 76 [emphasis in original].

45 John M Johnson, "In-Depth Interviewing" in Jaber F Gubrium \& James A Holstein, eds, Handbook of Interview Research: Context and Method (Thousand Oaks, Cal: SAGE, 2001) 103 at 113. See also Greg Guest, Arwen Bunce \& Laura Johnson, "How Many Interviews Are Enough? An Experiment with Data Saturation and Variability" (2006) 18:1 Field Methods 59 at 60.

46 Johnson, supra note 45.

${ }^{47}$ Creswell, supra note 44 at 81.

${ }^{48}$ Morten Huse \& Anne Grethe Solberg, “Gender-Related Boardroom Dynamics: How Scandinavian Women Make and Can Make Contributions on Corporate Boards" (2006) 21:2 Gender Mgmt 113 at 126 ("In this study we have had a focus on women. ... We have not collected stories from men. . . Future studies could benefit from the experiences ... . [of] various groups of male directors."). I also thank Doreen McBarnet for encouraging me to include men in the sample.
} 
Not a final version. Final version forthcoming in Challenging Boardroom Homogeneity: Corporate Law, Governance, and Diversity (Cambridge University Press, 2015)

\section{Findings}

A number of consistent patterns emerge from this exploratory, illustrative study. I discuss these patterns, along with the other central results of the investigation, in the section that follows. Overall, in these wide-ranging interviews, I canvassed a wealth of important topics relevant to the global board diversity conversation. I have chosen to focus here on two particular themes and corresponding research questions, which I referenced above and present more concretely in Table 4.4, below. These specific subjects, I believe, are especially helpful in illuminating the deeper complex meanings of the forced repopulation of boards along gendered lines.

Table 4.4 - Themes and corresponding research questions

\begin{tabular}{|l|l|}
\hline Theme & Research questions \\
\hline 1. Reactions to the quota law & $\begin{array}{l}\text { What were the overall societal and director-specific } \\
\text { reactions to the quota law? } \\
\text { What cultural and socio-political factors informed these } \\
\text { reactions? }\end{array}$ \\
\hline $\begin{array}{l}\text { 2. The quota law's meaning and } \\
\text { effects }\end{array}$ & $\begin{array}{l}\text { How has legally mandated gender balance affected } \\
\text { boardroom cultural dynamics, decision making, and overall } \\
\text { firm governance? } \\
\text { Mindful of the discourse surrounding potential stigmatizing } \\
\text { effects, how have women directors subjectively experienced } \\
\text { the effects of the quota law? What has "invading" the space } \\
\text { of corporate governance meant to them? }\end{array}$ \\
\hline
\end{tabular}

\section{A. Societal reactions to the quota law}

\section{(i) General acceptance}

Participants reflected on the initial reaction of Norwegian society as a whole to the quota law's implementation and on how particular subsets, such as businesspeople, politicians, and the media, responded as well. Many spoke of early resistance in the population at large, citing the commonly held view that the law would be unsuccessful in practice or would cause insurmountable compliance difficulties. Others noted that many in Norway were simply in a state of surprise or disbelief. A number of interviewees suggested that the reaction of male corporate directors tended to be particularly negative or skeptical. While an almost equal number felt that the male reaction was varied, and could not be generalized, most who expressed this view also felt that whether Norwegian men supported or opposed the law depended on whether, and to what extent, they perceived it as a threat to their own board positions and to traditional modes of governance.

Nonetheless, despite a difficult adjustment period, the initial heated debate in Norway appears to have largely subsided. ${ }^{49}$ While in some countries the prospect of such aggressive intervention in corporate governance cultures is the subject of intense controversy, the reality of such intrusion in Norway appears to have been generally accepted. One participant remarked that with "every year that

\footnotetext{
${ }^{49}$ This, of course, is not to suggest that there is uniform support for the law. As Hoel notes, "Opponents ... still argue the principle that owners should have the right to appoint board members of their choice." Marit Hoel, "The Quota Story: Five Years of Change in Norway" in Susan Vinnicombe et al, eds, Women on Corporate Boards of Directors: International Research and Practice (Cheltenham, UK: Edward Elgar, 2008) 79 at 86.
} 
Not a final version. Final version forthcoming in Challenging Boardroom Homogeneity: Corporate Law, Governance, and Diversity (Cambridge University Press, 2015)

passes, people get more used to [the quota law] and find it more and more natural." ${ }^{50}$ Another compared the quota law's normalization process to a previously enacted law banning smoking in all public places:

[I]t's like the 'no-smoking' law in Norway. We were [one of] the first to ban smoking in all public restaurants and the rest of the world thought we were [some] sort of crazy police state. But now, a lot of other countries have done the same! And in Norway it was so controversial, people were so angry, but after it was implemented, no one [has] regrets anymore..$^{51}$

While various dynamics likely account for this acceptance, almost three-quarters of respondents identified three particular socio-political factors as playing an integral role in rendering the law palatable. First, many interviewees felt that the two-year phase-in period allowed affected companies to adjust gradually to the coming mandate and to prepare both mentally and practically for the changes it would require. This gradualism served to reduce resistance and practical problems when the mandatory quota came into effect. One participant suggested that the voluntary period was less of a factor than the first-in-time quota for state-controlled firms. She suggested that the government's willingness to apply the controversial measure to firms in which it was a major owner set an example for the rest of industry.

Second, directors cited Norway's political culture as an important determinant. Norway has a strong tradition of political party quotas, wherein parties voluntarily undertake to meet a specified level of gender representation amongst their contenders for public office. ${ }^{52}$ Beginning in 1975, Norway's Socialist Left Party adopted a 40 percent party quota. ${ }^{53}$ Since that time, four other prominent parties have followed suit. ${ }^{54}$ Many of these respondents were of the view that these measures have normalized the use of positive discrimination in Norwegian society, thus making the corporate quota less controversial than it may have been otherwise. Some also opined that party quotas have led to Norwegians becoming accustomed to women in positions of power; it is not anomalous for women to hold such positions and to succeed in them, and they are respected for doing so.

Third, directors in the sample ascribed the successful internalization of the quota law, and its overall effectiveness, to what one respondent referred to as the "philosophical underpinnings of the culture, $" 55$ in other words, to particular threads of the overall Norwegian social fabric. Most frequently, participants cited Norway's focus on egalitarianism and the presence of social democratic norms and traditions. They felt these values led to a readier acceptance of the quota law and of the idea of genderbalanced boardrooms, and helped to ensure that a qualified pool of female directors existed. More concretely, some observed that Norway's overall corporate culture tends to be open and nonhierarchical as well as encouraging of parental leave, flex policies, and work-from-home policies, and that Norwegian companies already deal with laws mandating employee representation on the board in certain circumstances (the codetermination system). ${ }^{56}$ Others noted that much of the female population

\footnotetext{
${ }^{50}$ Interviewee 8, Transcript, at 27.

${ }^{51}$ Interviewee 2, Transcript, at 15.

52 Mona Lena Krook, Quotas for Women in Politics: Gender and Candidate Selection Reform Worldwide (New York: Oxford University Press, 2009) at 7.

53 Ibid at 230.

${ }^{54}$ Ibid; Teigen, supra note 20 at 75.

55 Interviewee 7, Transcript, at 19.

${ }^{56}$ For the specifics of Norway's codetermination system, see Sjåfjell \& Kjelland, supra note 6 at 716.
} 
Not a final version. Final version forthcoming in Challenging Boardroom Homogeneity: Corporate Law, Governance, and Diversity (Cambridge University Press, 2015)

in Norway is well educated, which means that women are active participants in the labor market and are thus either qualified to serve as board directors or able to become qualified.

Also on this front, some discussed the division of household labor and childcare, pointing out that government social benefit policies and general society norms tend to result in Norwegian men absorbing some portion of household or childcare responsibilities. Participants generally suggested that these policies and norms afford Norwegian women the necessary time and ability to develop their careers and to seek out board service. Recent data from the Organisation for Economic Co-operation and Development (“OECD") supports interviewees' observations about the division of labor. Of OECD member states, Norway ranks second-after Denmark-in terms of male time spent performing unpaid work, including housekeeping, caring for family members, and shopping. ${ }^{57}$ With respect to particular state-related measures, the government's current paid parental leave policy requires that the father take a specific number of weeks (ten) and the mother take an equal amount. The parents may divide the rest of the paid leave period as they choose. ${ }^{58}$ The official purpose of the "paternal quota" is "to encourage fathers to participate more in caring for their infant." ${ }^{59}$ So deep-seated is the commitment to gender equality that Norway even has a gender-conscious kindergarten plan. Indeed, under the state "Framework Plan for the Content and Tasks of Kindergartens," consciousness-raising begins at a young age: "The activities in the kindergartens must be based on the principle of gender equality. Boys and girls must have equal opportunities to be seen and heard, and encouraged to join in together in all the activities that go on in the kindergarten." ${ }^{60}$

\section{(ii) Director support and a narrative of change}

On balance, a strong majority (almost three-quarters) of corporate directors in the sample indicated their own personal support for the law. This includes almost all female respondents and half of the males. ${ }^{61}$ A minority either opposed the law or indicated a willingness to tolerate or accept it, or did not express a clear position. The majority of directors in support of the law spoke to how their views had evolved, presenting a robust narrative of change. Almost two-thirds of proponents reported that they were initially opposed, hesitant, or agnostic about quotas. It was only after seeing the quota law in action and directly experiencing its effects that they eventually came to endorse it. ${ }^{62}$ These results resonate with the conclusions of the preliminary, survey-based study that Groysberg and Bell conducted, which found that "contrary to popular belief . . . men in countries with quotas supported

\footnotetext{
57 OECD, "Balancing Paid Work, Unpaid Work and Leisure" (7 March 2014), online: <www.oecd.org/gender/data/balancingpaidworkunpaidworkandleisure.htm>, <www.oecd.org/gender/data/OECD 1564 TUSupdatePortal.xls >.

58 Norwegian Labour and Welfare Service, "Parental Benefit" (3 July 2014), online: $<$ https://www.nav.no/Parental+benefit.353588.cms>.

${ }^{59}$ Norwegian Labour and Welfare Service, "Paternal Quota before 1 July 2013" (2014), online: <https://www.nav.no/English/English/Paternal+quota+before+1+July+2013.805369152.cms>.

${ }^{60}$ Norway, Ministry of Education and Research, "Framework Plan for the Content and Tasks of Kindergartens" (2012) at 10, online: <www.regjeringen.no/upload/KD/Vedlegg/Barnehager/engelsk/Act no 64 of June 2005 web.pdf>.

${ }^{61}$ See also Cathrine Seierstad, "Gender Quotas on Corporate Boards in Norway, Necessary but Not Ideal" in Machold et al, supra note 25, 138 at 142 (interviewing twenty-two female Norwegian board members and finding "that women express preference for radical [affirmative action]").

${ }^{62}$ See also Claire Braund, "To Investigate the Effect of Gender Quotas on Public Listed Company Boards In Norway and the Progress of the Public Policy Debate in the UK and France" (np: Winston Churchill Memorial Trust, 2012) at 22, online: Women on Boards <http://www.womenonboards.org.au/pubs/reports/clairebraund-churchillfellowship-report.pdf $>$.
} 
Not a final version. Final version forthcoming in Challenging Boardroom Homogeneity: Corporate Law, Governance, and Diversity (Cambridge University Press, 2015)

them in higher numbers than men in countries without them" and that "[n]early all the female directors from countries with quotas agreed they were effective, versus about half of the female directors from countries without quotas. ${ }^{\prime 63}$ The remarks of two female directors are illustrative:

[I]t's a really, really difficult question. At first, I thought, 'What on earth is this? I don't want to be quota-ed into anything! . . I'm sure you can imagine yourself, it doesn't feel very good that you're recruited because you have to be recruited. ... [S] o first I was ... . negative.... [But] you have to do something extreme to get a change, like we've done in Norway. ... I think in general the people are happy with the quota laws, apart from, . .. (mimicking) 'We don't like to be regulated.' ... It's been positive. . . . I support it. . . . [l]t's been good for . . . the way [boards] work. ${ }^{64}$

I'm convinced normally that quotation is not a good idea, and I'm skeptical to most kinds of quotations generally. But what I see after this law has been effected, is that suddenly there are a lot of clever young women that I didn't know before. I hadn't heard about them, I didn't know they existed. . . . [T]here was a tendency to what we call the 'man's club syndrome.' You know: they ask the men . . . they go out with or have their club with. So there was a self-recruiting system in a way, where the old men recruited the other old men and suddenly you had the ... very little group that was on all of the boards. ... [I]t's been very refreshing to see all these young, clever, competent, strong women coming out of nowhere and actually doing a very good job. . . . I didn't foresee that effect. And that's why l've had to say that I have changed my perspective. I'm much more positive to it now. ${ }^{65}$

Another respondent remarked that women who were originally opposed to the law were "typically women that . . . had made . . careers the hard way, . . climbing the ladders without any help, so to speak." In this (female) interviewee's opinion, these senior women had initially believed that the law would push unqualified females to their level "without having to work for it." These women, however, subsequently changed their minds because of "how successful the quota law's been and how it's actually been contributing to better quality in . . . the board's work." ${ }^{66}$

These reflections notwithstanding, a number of participants who endorsed the law also expressed reservations, some mild and some strong. In general, when exploring whether they were ultimately in favor of the law, most of the responses reflected a kind of internal monologue or struggle; even if a director supported or opposed the quota overall, he or she still recognized negative or positive aspects to it. As one female director commented: "I'm not completely comfortable with it still. It still irks me. But I see . . . what's happened and I think it's very good, the result." ${ }^{67}$ Interestingly, this internal struggle sometimes appeared to cause respondents to question their own deeply held beliefs. In one case, for example, a female director made it clear that she loathes governmental meddling in the private sphere. Additionally, she expressed her disagreement with those who would suggest that board membership is a "female . . right." That said, she ultimately supported the quota law because, in her view, it was a necessary evil in disrupting the closed networks that had previously dominated

\footnotetext{
63 Boris Groysberg \& Deborah Bell, "Dysfunction in the Boardroom: Understanding the Persistent Gender Gap at the Highest Levels", Harvard Business Review 91:6 (June 2013) 88 at 97.

64 Interviewee 17, Transcript, at 10-11.

65 Interviewee 13, Transcript, at 9-10.

66 Interviewee 19, Transcript, at 16.

${ }^{67}$ Interviewee 7, Transcript, at 15.
} 
Not a final version. Final version forthcoming in Challenging Boardroom Homogeneity: Corporate Law, Governance, and Diversity (Cambridge University Press, 2015)

boardrooms. It was almost as if she was grudgingly accepting that the free market principles she held so dearly had disappointed her-and that the quota was a necessary correction of market failure. ${ }^{68}$

I was particularly interested in exploring whether a tension existed in the views of directors who first received ASA board appointments prior to the quota's implementation ("group one") and those who first received appointments during the transitional or mandatory periods ("group two"). Do the men and women who entered the boardroom subsequent to the law have a more positive view of it than those who had previously become directors? In analyzing the responses of both comparator groups, group two expressed a slightly stronger preference for the law; eight out of ten in group two indicated support for the law, whereas six out of nine in group one expressed support. That said, group two also expressed stronger reservations. Overall, in considering the totality of responses, there does not appear to be any substantial, noteworthy difference. Both the "new directors on the block" and the directors who preceded them tend to speak favorably about the forced inclusion of gender diversity.

When asked if they would recommend quotas to other countries currently considering regulatory possibilities to address board homogeneity, most directors (almost two-thirds) responded affirmatively. Naturally, some of these respondents qualified their answer by adding that their recommendation would be conditional on the presence of certain integral factors, such as the existence of a sufficient pool of qualified, educated female candidates (harkening back to the socio-political and cultural factors discussed above). Following from this, I asked interviewees about various possibilities for the drafting and implementation of the quota law. Should the law have been crafted or operationalized in a different way? While most were satisfied with the status quo, a significant minority discussed alternatives, either because of dissatisfaction with the existing law or simply as hypothetical possibilities. The most common alternatives they proposed included: (1) reducing the harshness of the penalty for noncompliance by using fines, rather than dissolution; (2) providing companies with more time to reach compliance; and (3) using a more gradual quota system with initial targets lower than 40 percent, with a view towards eventually reaching 40 percent over a number of years.

\section{B. The quota law's meaning and effects}

To the extent that directors in the sample changed their minds about the quota law, such that it now enjoys support, ${ }^{69}$ the natural question is 'why?' At the time of the interviews, the law had been compulsory for more than three years. Did witnessing the law in operation cause a general shift in opinion? Overall, interviewees provided a range of reasons for their endorsement of the law, including that it has harnessed the entire talent or resource pool available in society; that it has been efficient, in that it has increased the levels of female representation on boards in a short amount of time; and that it has promoted equal opportunities for men and women.

Throughout the interviews, often without regard to the particular question asked, respondents emphasized that the law had simply worked-it had achieved positive results. But what precisely were

\footnotetext{
${ }^{68}$ Interviewee 3, Transcript, at 9-10. Some economists have also characterized the market's inability to incorporate the contributions of women as a sign of failure. See TD Economics, "Get on Board Corporate Canada" (7 March 2013) at 1, online: <http://www.td.com/document/PDF/economics/special/GetOnBoardCorporateCanada.pdf>. More generally, see J Robert Brown, Jr, "Women on the Board and Market Failure (Part 2)" (25 March 2010), online: The Race to the Bottom <www.theracetothebottom.org/independent-directors/women-on-the-board-andmarket-failure-part-2.html> ("The number of women on the boards of US companies (and those elsewhere) reflect 'market' failure. Really they reflect a non-existent market. To rely on the 'market' to solve the problem is to present no solution at all.").

${ }^{69}$ Though, as noted above, often with reservations.
} 
Not a final version. Final version forthcoming in Challenging Boardroom Homogeneity: Corporate Law, Governance, and Diversity (Cambridge University Press, 2015)

those results? A dominant narrative among participants, both male and female, was that gender diversity has a positive effect on the process and substance of board decision making and the board's overall governance culture.

The gender-related benefits that respondents perceived can be broken down into the categories of characteristics and outcomes. Characteristics are traits or differences that female directors are thought to possess or bring to their board work. In identifying these attributes, some interviewees initially expressed trepidation about gender stereotyping, but they then explicitly drew the connection between gender and particular valuable attributes. Outcomes, on the other hand, are changes gender diversity brings to the way members of the board work or to the way the board operates as a whole. These changes could either appear as a direct result of increased heterogeneity or as the combined effect of the various gender-specific characteristics identified. Not every response fit neatly into one of these two categories, and a number of responses overlapped. Further, a small minority felt that the overall perceived positive effects of gender diversity manifest either in specific situations only or when combined with other factors, such as age. Nonetheless, these categorizations describe the overarching impressions of the sample population.

\section{(i) Characteristics}

The positive gender-specific "characteristics" that respondents identified fell into four subcategories: (1) intellectual and experiential diversity; (2) diligence; (3) outsider status/independence; and (4) style of engagement. Of these, the first three arose most frequently in the data; the fourth was noteworthy, but less prominent.

First, participants offered a compelling account of female directors' intellectual and experiential diversity. Most felt that women bring to the boardroom, and to the decision making that occurs therein, a different set-or broader range-of perspectives, experiences, angles, and viewpoints than their male counterparts. As I discuss in more detail in the next section, interviewees believed a range of effects flowed from the presence of this cognitive difference. Most typically, respondents said that diverse perspectives and ideas provide a broader basis for decision making. Others felt that the presence of varying perspectives contributes to long-term, stable value creation and preservation or the overall long-term survival of the company.

With respect to why female directors in particular bring intellectual and experiential diversity to the boardroom, most felt that there was something specifically related to gender at play. Women directors either have uniquely "female perspectives" or have developed different perspectives from men due to different life experiences or different employment and experiential backgrounds. One female director emphasized that the value-added of this dynamic results from the balance achieved by mixing the experiences and perspectives of women with that of men. After describing her most recent CEO position as involving "a board of well, mostly men, all thinking with their calculators," and noting the benefits of the viewpoint range women bring, she observed:

[B]elieve me, ... I know generalizations are wrong. ... [B]ut ... I think a board without men, generally, would mean the company didn't get anywhere. . . Because they are

risk-seeking, they are out there, they are doing it, they don't have [the] second thoughts 
Not a final version. Final version forthcoming in Challenging Boardroom Homogeneity: Corporate Law, Governance, and Diversity (Cambridge University Press, 2015)

that women tend to have. But if you balance these perspectives, you get better decisions. $^{70}$

Second, respondents presented a vivid narrative of diligence. Most frequently, they observed that female directors are more likely than their male counterparts to probe deeply into the issue at hand. They accomplish this via the assertive presentation of inquiries. Women, it was felt, ask more questions, more challenging questions, more interesting and counter-intuitive questions, or even socalled "stupid" questions. ${ }^{71}$ Mirroring the findings of qualitative studies on US and Canadian boards, interviewees suggested that males "are more afraid to show that they might not know everything. . . . [T]o show that they're not experts on everything." ${ }^{72}$ This particular female director observed that sometimes when women become inquisitive, "the men look very relieved, . . . [because] they didn't know [the answer] either." ${ }^{\text {73 }}$ Another male director stated: "[I]f you have a board with five people like me. They're all ... from the same school, of the same age, they have the same background, they have been studying finance. ... [W] tend to ask questions and we want to spend time on items we have a lot of knowledge [on]. . . . If you have different experiences and a more diversified board, you will have different questions asked." ${ }^{74}$

Interviewees offered a range of responses when pressed as to why female directors probe more. Some observed that women directors tend to be younger and in earlier stages of their career, or are lacking in industry experience more generally. Interestingly though, only a few respondents offered this view. More frequently, participants tended to attribute the inquisitiveness to the possibility that women are uninterested in presenting a façade of knowledge and are loath to make decisions they do not fully understand or take material components of a decision for granted.

Also on the theme of diligence, and consonant with the findings of previous qualitative studies, ${ }^{75}$ others pointed out that female directors are more prepared for board meetings (e.g., they read documents more thoroughly), insist on more information prior to making a decision in order to anchor that decision (e.g., they tend to seek more fulsome documentation), and are otherwise more conscientious generally (e.g., they are more responsible and reliable, are willing to put in more effort when required, and take their work more seriously).

Third, interviewees frequently portrayed female candidates as outsiders, or as existing separate and apart from prevailing male-dominated board structures. Throughout the conversations, in addition to using the outsider motif, respondents also utilized the related discourse of independence. Participants emphasized that the law has severed or broken up close ties amongst directors, or between directors

${ }^{70}$ Interviewee 11, Transcript, at 7-8.

71 Interviewee 23, Transcript, at 7.

72 Interviewee 13, Transcript, at 6. See Patricia Bradshaw \& David Wicks, "The Experiences of White Women on Corporate Boards in Canada: Compliance and Non-Compliance to Hegemonic Masculinity" in Ronald J Burke \& Mary C Mattis, eds, Women on Corporate Boards of Directors: International Challenges and Opportunities (Dordrecht, the Netherlands: Kluwer Academic, 2000) 197 at 207 (“I don't think men want to appear as if they are not knowledgeable about something."); Vicki W Kramer, Alison M Konrad \& Sumru Erkut, "Critical Mass on Corporate Boards: Why Three or More Women Enhance Governance" (2006) Wellesley Centers for Women, Report No WCW 11 at 14 [emphasis in original] ("A male CEO claimed the men 'felt a gender obligation to behave as though they understood everything.'").

73 Interviewee 13, Transcript, at 6.

74 Interviewee 15, Transcript, at 4.

75 Huse \& Solberg, supra note 48 at 124 ("All the women gave comments on preparations for the meetings. Women were in general, better prepared than men."). 
Not a final version. Final version forthcoming in Challenging Boardroom Homogeneity: Corporate Law, Governance, and Diversity (Cambridge University Press, 2015)

and other company players, such as the CEO and senior management generally. While some espoused the virtues of independence at a general level, indicating that it is essential to good governance, many others took this a step further by specifically linking independence with the idea of women as "outsiders." These interviewees suggested that female candidates often come from "non-traditional" networks that tend not to overlap with those of men. Correspondingly, one female director described the recruitment of female candidates as selecting "someone out of the inner circle," "out of their inner sphere," or from "a little bit further away."76

How did participants explain this outsider status? It stems largely from not being in the same social networks as men and from standing on the periphery of specific sets of male relationships, such as those based on sporting activities. Interviewees commented, for example, that men are part of "the same golf club" ${ }^{77}$ or "golf clubs," "78 and generally are part of a "man culture" in which men have "things they are doing together where no woman is involved," such as "rotary" clubs, "hunting and fishing" and "football games." ${ }^{\prime 79}$ Further, interviewees used terms denoting the tight-knit nature of these male relationships and their inextricable social element, referring to some male boards as a "gang of friends," ${ }^{80}$ an "inner circle," ${ }^{11}$ an "old boys' network," ${ }^{\prime 2}$ and "a bunch of . . . buddies" or a "bunch of friends" who "go out to have beers together every Friday." ${ }^{83}$ One interviewee remarked on the pattern of "friends recruiting friends into the boardrooms." ${ }^{84}$ Another noted that the business world, specifically the C-suite, is still mostly "a male community" whose social network is informal in that it is "like the boys go out and have a beer." ${ }^{\prime \prime 5}$

Fourth, some participants observed that female directors tend to have a different style of engagement. Their approach to leadership and decision making was thought to be more relational and to promote a dynamic of participation and collaboration on the board. ${ }^{86}$ They are more likely to elicit the opinions of others and to try to ensure that everyone in the boardroom takes part in the discussion. It was evident that some female directors consciously viewed this approach as a means of more effective communication. One, for example, indicated that a relational method gets her "opinion across in a better way" and that she is "maybe . . heard better." ${ }^{87}$ Another suggested that employing such a method in discussing possible alternative solutions or decisions "get[s] the other[s] on the board to actually think more and to weight other possible solutions as well." 88 This participant contrasted such behavior with what she perceived as a male tendency to "jump to conclusions" without necessarily examining all implications or possible alternatives. ${ }^{89} \mathrm{~A}$ third described the gendered dynamic of

\footnotetext{
${ }^{76}$ Interviewee 17, Transcript, at 10, 9, 7.

77 Interviewee 23, Transcript, at 6.

${ }^{78}$ Interviewee 14, Transcript, at 8.

${ }^{79}$ Interviewee 6, Transcript, at 9.

${ }^{80}$ Interviewee 17, Transcript, at 7.

${ }^{81} \mathrm{lbid}$ at 10.

82 Interviewee 2, Transcript, at 13.

${ }^{83}$ Interviewee 3, Transcript, at 24, 7.

${ }^{84}$ Interviewee 16 , Transcript, at 8.

85 Interviewee 17 , Transcript, at 8.

${ }^{86}$ This echoes the findings of studies on US boards. See Kramer, Konrad \& Erkut, supra note 72 at iv ("We find that women . . . bring a collaborative leadership style that benefits boardroom dynamics by increasing the amount of listening, social support, and win-win problem-solving.").

${ }^{87}$ Interviewee 7 , Transcript, at 10.

${ }^{88}$ Interviewee 8, Transcript, at 7.

${ }^{89}$ Ibid.
} 
Not a final version. Final version forthcoming in Challenging Boardroom Homogeneity: Corporate Law, Governance, and Diversity (Cambridge University Press, 2015)

participative decision making in the following way, simultaneously querying aloud whether the perceived difference is best attributable to biology, cultural socialization, or both:

[1]t is my personal observation that men and women interact differently in the boardroom.... [A] male [decision-making] round would be like the men are confirming each other like a football team. ... [T] he spokesman . . . utters an opinion . . . in a matter, and the next man will simply confirm him. .. . [T] he decision . . . has been understood and sometimes even communicated before the board meeting. So it's only a confirmation taking place in the boardroom. Whereas women ... will come to the board and be more interested in having a real work session where everybody utters their opinion, you agree on something in the meeting. . . I'm not saying that one culture or working procedure is better than the other. They're just different. ${ }^{90}$

\section{(ii) $\quad$ Outcomes}

In this section, I discuss what my data show are some of the consequences of gender-based heterogeneity for boardroom work and dynamics. Throughout the interviews, respondents linked some or all of the qualities identified above with seven potential outcomes: (1) enhanced dialogue; (2) better decision making; (3) more effective risk mitigation and crisis management; (4) higher-quality monitoring of, and guidance to, management; (5) positive changes to the boardroom environment or culture; (6) more orderly and systematic board work; and (7) positive changes in the behavior of men. Respondents most commonly cited outcomes one through five, but also identified outcomes six and seven with some frequency.

Of course, directors appointed after the quota law came into effect cannot meaningfully compare current boardroom dynamics with those in place prior to the law's enactment. Their limited vantage point must therefore be taken into account when putting the data in perspective. Mindful of this limitation, it was especially important to include in the sample directors who had attained their initial ASA appointments prequota. As discussed above, almost 40 percent of the interviewees fell into that category. As with the question of whether directors supported the quota law, I sought to learn whether directors who had served on ASA boards before the quota came in effect ("group one") viewed the consequences of the law differently from those whose initial entry into the ASA boardroom came during the transitional or mandatory period ("group two"). Once again, there was little tangible difference between the "new directors on the block" and the directors who preceded them. Seven out of ten in group two believed that increased diversification had had a positive impact on board decision making, governance, or culture, whereas seven out of nine held that view in group one.

I turn now to the outcomes highlighted above. First, many respondents contended that gender diversity promotes enhanced dialogue. Interviewees frequently spoke of their belief that heterogeneity has resulted in: (1) higher quality boardroom discussions; (2) broader discussions that consider a wider range of angles or viewpoints; (3) deeper or more thorough discussions; (4) more frequent and lengthier discussions; (5) better-informed discussions; (6) discussions that are more frequently brought inside the boardroom (as opposed to being held in spaces outside the boardroom, either exclusively or in addition to inside the boardroom); or (7) discussions in which items that directors previously took for granted are drawn out and addressed-where the implicit becomes explicit. ${ }^{91}$

\footnotetext{
90 Interviewee 5, Transcript, at 9-10.

${ }^{91}$ For similar findings in the US context, see Alison M Konrad, Vicki Kramer \& Sumru Erkut, "Critical Mass: The Impact of Three or More Women on Corporate Boards" (2008) 37:2 Org Dynamics 145 at 156.
} 
Not a final version. Final version forthcoming in Challenging Boardroom Homogeneity: Corporate Law, Governance, and Diversity (Cambridge University Press, 2015)

Second, and intimately related, many interviewees indicated that diversification has led to (or has the potential to lead to) better decision making processes and/or final decisions. Here, respondents focused on the enhanced quality of the procedure and the resulting outcome. Even when a diverse board's ultimate decision was not substantively different than one that a purely or predominantly male board would take, respondents suggested that a diverse board would nonetheless engage in highercaliber decision making, more thoroughly canvass the decision's implications, and act on a more informed basis with better information, thus improving the decision's implementation. One female director illustrated these sentiments with the following remarks:

[T]here are more discussions.... [T] he women are the skunks. ... They ask the difficult questions, ... they want to examine an issue from all angles or more angles.... [T] here is less risk involved in the decisions [because] you have explored different aspects. . . . $[T]$ hey [women directors] are very conscientious, they prepare, they really want to . . . do a good job. ... . [O]ften in boards, with the old boys' network ... I say, "I'm sure you've discussed this a lot of times before, but" ... and I ask the question. And I see them looking at each other. And you can see they've never discussed it! $!^{92}$

Third, interviewees frequently suggested, explicitly or implicitly, that the presence of women in the boardroom informs risk mitigation or adds particular value during situations of crisis. On the first front, a number indicated that boards with gender diversity tend to be more risk averse or consider riskbased implications more often or seriously. Some of these respondents explicitly attributed this to the view that female directors tend to be more cautious or risk averse than males. Amongst these directors, it was thought that female directors foresee and wish to address future problems sooner than their male counterparts. Some framed this as thinking of "worst-case scenario[s]," ${ }^{13}$ while others framed it as female directors trying to prevent future problems, such as preventing lawsuits or trying to reach decisions that will prove useful not just in the moment but also a "few years down the road." 94

As with intellectual diversity, some took care to highlight the need to establish an equilibrium between the "male" risk-welcoming behavior and "female" risk aversion that my interviewees portrayed. On the second front, some participants highlighted female directors' particular role and value in making especially difficult and/or controversial decisions when the firm was in a state of crisis. One female director was of the view that there is actually very little that distinguishes male and female behavior during routine board work. However, she poignantly spoke about how, in her view, this changed during moments of crisis or emergency:

I feel in a couple of situations that were very, very critical, then I saw [the] difference between how men and women behave. ... I've seen situations where the women were more willing to dig into the difficult questions and to really go to the bottom even if it was extremely painful both for the rest of the board, but . . . mostly for the CEO. . . . $[T]$ he really difficult situations, [where] you think that the CEO has ... done something criminal ... [o]r you think that he has done something negligent, something that makes it such that you .... are unsure whether he's the suitable person to be in the driving seat. $^{95}$

\footnotetext{
${ }^{92}$ Interviewee 2, Transcript, at 7, 13.

${ }^{93}$ Interviewee 10, Transcript, at 19.

${ }^{94}$ Interviewee 9, Transcript, at 8.

${ }^{95}$ Interviewee 14 , Transcript, at 6, 8.
} 
Not a final version. Final version forthcoming in Challenging Boardroom Homogeneity: Corporate Law, Governance, and Diversity (Cambridge University Press, 2015)

Fourth, many respondents drew a connection between gender-diverse boards and increased or higher-quality monitoring of management and guidance provided to management. These directors felt that heterogeneous boards tend to challenge management more, or to impede patterns of "groupthink" (the tendency of persons in closely bonded groups to pursue consensus without critical evaluation and without considering different possibilities), ${ }^{96}$ which, in turn, increases the probability of critically engaging management. One female director, after positing that women are more likely to question management and to be independent, discussed the pernicious effects of groupthink on board work, stating that "men are more ... afraid of exposing one another." She attributed this to elements of what she described as "man culture":

I think there's a man culture, in some way. ... [I]f you go back in time, they have these things they are doing together where no women are involved. They have this rotary, they have ... [these] clubs or organizations where ... there are only men. ... And they have this hunting and fishing thing, and they have [these] football games, and . . I I think they are ... more afraid of exposing one another. ${ }^{97}$

Some participants in this group also suggested that female directors request more updates from management or CEOs and devote more attention to monitoring the implementation of strategy and its progress. That said, as noted, responses falling into this group did not pertain exclusively to monitoring, but also extended to the board's role in counselling and assisting management. Participants spoke of the connections between diversity and the ability to "guide management." ${ }^{\prime \prime 8}$ As one female director stated:

I try to support management. I feel a lot of times most board members in general are much more concerned about finding some fault in the materials, fault in their arguments ... and try to control and regulate ... what the ... [management] is doing. . .. I'm more concerned with trying to support management and trying to encourage them, trying to help them be motivated. ... And I think that ... has to do with me being a woman. ${ }^{99}$

Fifth, interviewees often offered the view that diversification had changed the overall boardroom environment or culture. Most frequently, this meant that the atmosphere around the board table was more open, less severe, and one in which directors felt comfortable or "safe" contributing to board discussions and asking questions. ${ }^{100}$ This includes increased tolerance of varying opinions. Some respondents also mentioned a more fun working atmosphere-that increased diversity has changed the tone of board work, making it a more enjoyable, collegial experience, or that it has added a positive energy to the work conducted. One director described this as a transformation to an "open-minded board" that "opens up for everybody, regardless of woman or man."101

\footnotetext{
96 Irving L Janis, Groupthink: Psychological Studies of Policy Decisions and Fiascoes, 2d ed (Boston, Mass: Wadsworth, 1982) at 9.

97 Interviewee 6, Transcript, at 9.

98 Interviewee 7, Transcript, at 9; Interviewee 22, Transcript, at 13.

99 Interviewee 19, Transcript, at 24-25.

100 Interviewee 13, Transcript, at 21-22. Along similar lines, see the findings in Huse \& Solberg, supra note 48 at 121.

101 Interviewee 17, Transcript, at 23-24.
} 
Not a final version. Final version forthcoming in Challenging Boardroom Homogeneity: Corporate Law, Governance, and Diversity (Cambridge University Press, 2015)

Sixth, a number of participants suggested that diversified boards lead to more professional work cultures and to more systematized board work. ${ }^{102}$ The nexus between gender representation and a shift to more structured, systemic processes was thought to manifest itself in a number of ways, including: establishing or improving formal protocols, procedures and systems; clearly defining the scope or mission of the board; ensuring that the board remains on task and follows existing rules and procedures; ensuring that management prepares for board meetings and provides board members with relevant information and an agenda; mandating formal meetings for certain tasks; making board meetings more structured; requiring more information and documents; and ensuring that meetings are run properly. Interviewees did not think the implications of such systemization were merely academic. One interviewee, for example, drew on the case of a company that found itself on the front page of the newspaper in a pollution-related whistleblowing situation. The firm "found out the hard way that [it] didn't have a whistleblower . . . procedure in place." ${ }^{103}$ Linking this to the theme of risk discussed above, she indicated that this kind of exposure would not have occurred with a gender-diverse board-that "women on boards make sure that all these kinds of procedures are there." ${ }^{104}$

Finally, some participants suggested that increased gender diversity on boards had induced changes in the behavior of male directors or of management when interacting with the board. Some participants, for example, opined that the tendency of female directors to be better prepared has induced better preparation in their male colleagues or has led to an improvement in, as one male director put it, "the normal male habits," such that board work has become more systematic and disciplined. ${ }^{105}$ Consistent with research findings in jurisdictions such as the United Kingdom, some also observed a shift in tone, as male directors were thought to act in a less macho, stereotypically male fashion. ${ }^{106}$

As respondents' representations reveal, the characteristics of female board members I described in the previous section have informed these outcomes to varying degrees. Of these characteristics, outsider status was a particularly powerful factor, informing outcomes such as: enhanced dialogue and decision making; monitoring and guiding management; risk reduction; crisis management; and systematization of board work. Especially important for respondents was their perception that outsider status breaks up close ties-what one male director even characterized as "collusion." ${ }^{107}$ This dynamic of severing social bonds purportedly occurred on two levels: first amongst directors, and second between directors and the CEO or high-level management more generally. Amongst directors, women's outsider status led to more robust intraboard deliberations and to the posing of probing questions that might embarrass or challenge other board members-questions that intragroup members (male directors) would not necessarily pose to each other. Outsider status also led to the provision of higher quality advice to CEOs and senior management and to more effective

\footnotetext{
102 See also Agnes Bols $\varnothing$, Hilde Bjørkhaug \& Siri $\varnothing$ ysleb $\varnothing$ Sørensen, “Gender-Balanced Corporate Boards" in Machold et al, supra note 25, 136 at 137 (reporting the following from their Norwegian interview-based research: "It is often said that board work has become more professional.").

${ }^{103}$ Interviewee 8, Transcript, at 10-11.

104 Ibid at 11.

105 Interviewee 23, Transcript, at 5. Similarly, see the findings in Huse \& Solberg, supra note 48 at 119-20.

106 See Val Singh, "Transforming Boardroom Cultures in Science, Engineering and Technology Organizations" (July 2008) UKRC Research Report Series No 8 at 61-62, , online:

<http://www.theukrc.org/files/useruploads/files/resources/report_8_singh_report_1606_08.pdf>

107 Interviewee 23, Transcript, at 6.
} 
Not a final version. Final version forthcoming in Challenging Boardroom Homogeneity: Corporate Law, Governance, and Diversity (Cambridge University Press, 2015)

monitoring more generally; directors were more likely to voice important dissenting opinions and, at times, make difficult and unpleasant decisions such as firing the CEO. ${ }^{108}$

\section{(iii) Concrete examples of diversity's value}

The results described above resonate with those in the excellent study Broome, Conley, and Krawiec conducted regarding the views of US corporate directors on board diversity. ${ }^{109}$ The authors also found that public company directors typically grounded their enthusiasm for heterogeneity in the idea of viewpoint plurality and its production of more fruitful deliberations. ${ }^{110}$ They refer to this view as the "Bakke narrative," 111 invoking the 1978 US Supreme Court decision concerning university affirmative action. While the Court in that case declared the quota-based measures of UC-Davis medical school unconstitutional, Justice Powell in his plurality opinion concluded that race could be a factor in making admissions decisions in order to promote diversity. He wrote of the benefits of exposure to "the ideas and mores of students as diverse as this Nation of many peoples" and noted that medical students from diverse backgrounds "may bring to a professional school of medicine experiences, outlooks, and ideas that enrich the training of its student body and better equip its graduates to render with understanding their vital service to humanity."112

My findings differ in an important respect from theirs, however. Broome, Conley, and Krawiec observed that their sample provided "distinct echoes of Bakke," ${ }^{113}$ but concluded that the narrative is only "a theoretical narrative without concrete detail, a story without substance." ${ }^{114}$ While espousing the benefits of diversity at a surface level, when they pressed US directors in their sample for meaningful, tangible examples, the directors provided none. ${ }^{115}$ This absence of particulars led the authors to pose the question: "Why do our subjects, on the one hand, affirm board diversity as a goal while, on the other, they offer little substantive justification for pursuing it?"116 The authors speculate as to the cause, advancing the following possibility:

Perhaps the Bakke narrative has achieved a broad but shallow victory, a discourse-level hegemony that has few consequences for thought or action. ... [G]enuflecting in the direction of diversity has become a routine part of polite and politically correct

108 This resonates with the findings in Nancy Mclnerney-Lacombe, Diana Bilimoria \& Paul F Salipante, "Championing the Discussion of Tough Issues: How Women Corporate Directors Contribute to Board Deliberations" in Vinnicombe et al, supra note 49, 123 at 136, 126.

${ }^{109}$ While both of our studies pertain to gender, that of Broome, Conley, and Krawiec also addresses directors' views on race and ethnicity.

${ }^{110}$ Broome, Conley \& Krawiec, “Dangerous Categories", supra note 33 at 778.

111 John M Conley, Lissa L Broome \& Kimberly D Krawiec, "Narratives of Diversity in the Corporate Boardroom: What Corporate Insiders Say about Why Diversity Matters" in Jolanta Aritz \& Robyn C Walker, eds, Discourse Perspectives on Organizational Communication (Madison, NJ: Fairleigh Dickinson University Press, 2012) 201 at 220-21.

${ }^{112}$ Regents of University of California v Bakke, 438 US 265 at 313-14 (1978).

${ }^{113}$ Conley, Broome \& Krawiec, supra note 111 at 208.

114 Ibid at 220.

115 Ibid at 220-21. See also Broome, Conley \& Krawiec, "Dangerous Categories", supra note 33 at 786 ("[W]ith some exceptions, subjects usually could think of nothing, or offered examples that seemed trivial."); Kimberly D Krawiec, John M Conley \& Lissa L Broome, "The Danger of Difference: Tensions in Directors' Views of Corporate Board Diversity" [2013] U III L Rev 919 at 920 ("[I]t is very difficult for our respondents to provide examples from their experience of when board diversity has made a tangible difference.").

${ }^{116}$ Conley, Broome \& Krawiec, supra note 111 at 221. 
Not a final version. Final version forthcoming in Challenging Boardroom Homogeneity: Corporate Law, Governance, and Diversity (Cambridge University Press, 2015)

discourse. This has correlated with a modest increase in women and minorities on boards, though their representation may have reached a plateau. But, to judge by our sample, business people do not seem to be thinking very hard about the concept of diversity, and so have not come up with a coherent narrative about why it is important. $^{117}$

My analysis of the data thus far suggests that participants in my study of Norway displayed a very deep appreciation of diversity's tangible value. A majority of my respondents, however, went even further still, supporting their general observations of diversity's importance with concrete examples based on either first-hand experience or second-hand knowledge (from their impressions of other boards or impressions they gained from directors at other firms and contacts). Most of these directors did so immediately, in direct response to my questions. Others did so organically at other points during the interview, without prompting. One interviewee needed time to let the issue marinate, before revisiting it on his own in a different context and providing an answer.

Many who furnished concrete examples cited a prominent Norwegian company that had been embroiled in a serious corruption scandal and noted the specific role that the firm's female directors played in addressing the controversy. One female respondent described the case succinctly:

[T]op management had paid bribes to get contracts. . . But the board didn't really want to address it. ... There were three independent female board members in that board. . . . And they demanded ... transparency and action. And it resulted in the CEO leaving the company. . . . This would not have happened if they hadn't been on the board. These were strong, well-known female directors. ... So that's one example. ${ }^{118}$

For these participants, this firm's experience represented an affirmative case of gender diversity's positive effect on governance. ${ }^{119}$

Others in the sample provided examples unrelated to corruption. One (female) interviewee described her own careful, cautious approach to expansion during a bullish period for her company, immediately preceding the 2008 financial crisis. Despite the momentum toward growth in the boardroom, this director remained "very firm" in her apprehensions, on account of her concerns that the board's assumptions about continuing revenues might be flawed. As a result of this director's insistence and foresight regarding this risk, the company chose not to expand and, after the downturn, it continued to do well while many of its competitors did not survive. When pressed further, this respondent specifically attributed the quality of risk-consciousness to gender. Based on her experience, she offered the view that women tend to be more "cautious" and to consider the "worst-case scenario," whereas men do not. ${ }^{120}$ Another (male) respondent recounted his experience on the board of a company that had accidentally caused environmental damage. In his view, the female members of the board put forth "several perspectives" in response to the crisis, thereby "broadening the scope" of views presented in the discussions. For this director, this situation was a "good example" of how women have added particular value to boardroom deliberations by increasing the range of perspectives considered, a benefit that he said is strongest for "issues ... which can be controversial."121

\footnotetext{
117 Ibid.

118 Interviewee 2, Transcript, at 11.

${ }^{119}$ Not all interviewees agreed on this point; two directors denied that it was an affirmative case.

${ }^{120}$ Interviewee 10, Transcript, at 18-19.

${ }^{121}$ Interviewee 9, Transcript, at 8-10.
} 
Not a final version. Final version forthcoming in Challenging Boardroom Homogeneity: Corporate Law, Governance, and Diversity (Cambridge University Press, 2015)

A third (female) director chronicled her board service in the banking industry and noted the effects gender had on product marketing strategies: "I've noticed that there are totally different things we focus on compared to the men. ... [H]alf of the customers in the large banks are women but they tend to have the marketing campaigns as if only men were among the customers." ${ }^{122}$ In her view, women directors have "had a great influence" on this dynamic, resulting in "a new way of thinking around the customers." 123 She stressed that marketing campaigns with which she was familiar were "affected by the fact that we were females" and that this change "happened several times ... in more than one company." ${ }^{124}$ As she put it, "we have another, different everyday life, which gives us some angles that the men do not have." ${ }^{\prime 25}$ In a similar vein, a fourth (female) director recollected her role in correcting a firm's sexist online advertising. In doing so, she also attributed her reaction and proactivity to her gender:

I had noticed that this company had these internet pages with lightly-dressed women, to put it that way. . . . And I brought that up in the board. I said, "Hey, you guys ... I really think it's the absolutely wrong thing to do, and it pulls the attention away from the real story ...." ... [A]nd they changed the practice. ... [S]o that's a very concrete example. ... I asked, "Why is it like this?" and . . . a man might not have reacted and he would definitely not have brought it up as a problem. But I brought it up and they changed the practice. ${ }^{126}$

It is difficult, and perhaps impossible, to confidently account for the difference in the abilities of US and Norwegian directors to point to precise examples of gender diversity's effects on board work. It could be that there is no discernable reason informing this discrepancy. It could be that Norwegian corporate governance culture vests more power and authority in the board such that directors generally have a greater impact on the operations of the corporation. Or, it could be that because the representation of women on US public company boards is generally low, especially compared to quotabound Norwegian firms, there simply are not enough women to demonstrate an impact on governance. These questions should inform future comparative research investigations.

\section{(iv) The benefits of critical mass}

A notable feature of Norway's law is its requirement that public companies comply with varying degrees of gender representation depending on the size of their boards. As noted in chapter 3, if, for example, a board has nine directors overall, there must be at least four men and four women. If a board is larger than nine, both genders must constitute 40 percent of the total makeup, at a minimum. In smaller boards with four or five directors, there must be at least two men and two women. ${ }^{127}$ The requirement of gender balance thus ensures that women constitute a critical mass on corporate boards. I therefore sought to learn whether the experiences of the directors I interviewed shed any light on the value of having certain levels of female representation.

Critical mass theory, most notably advanced in Kanter's landmark work on gender and organizational cultures in 1970s corporate America, highlights the dynamics created by the presence of

\footnotetext{
122 Interviewee 13, Transcript, at 7.

123 Ibid.

124 Ibid.

125 Ibid.

${ }^{126}$ Interviewee 19, Transcript, at 12.

${ }^{127}$ Norway, supra note 8, s 6-11a(1).
} 
Not a final version. Final version forthcoming in Challenging Boardroom Homogeneity: Corporate Law, Governance, and Diversity (Cambridge University Press, 2015)

different proportions of different social groups relative to one another in different settings. ${ }^{128}$ Individuals who are present in only scarce numbers take on "token" status, while those who are numerous achieve "numerical dominance."129 For the former group, difficulties abound, such as alienation and being cast as a representative for all in their group, and the possibilities for success are much more limited. ${ }^{130}$ That said, "[a]s proportions begin to shift, so do social experiences." 131

The consequences for individual members of groups that have not achieved critical mass can be significant and troubling. Outgroup members can experience profound isolation and feel pressure to adopt the dominant group's perceived characteristics. In a UK study, for example, female directors and high-level managers working in male-dominated firm cultures have reported that they frequently felt lonely and excluded, and that their male colleagues were unwilling to take steps toward shaping a more inclusive, equitable atmosphere. Some reported that they were put into traps, subjected to sexual harassment, or intentionally deprived of support from male colleagues to evaluate whether they could cope. They faced a typical catch-22 of power dynamics: how to exercise power constructively, while ensuring that male directors and managers were not made to feel threatened and vulnerable in a way that would adversely impact the women's careers. ${ }^{132}$

This dilemma caused women to experience an internal struggle in which they weighed the political consequences of being too forthright. In navigating this tension, the women went through a self-transformation process that gradually made them "tougher" as a means of self-preservation, though some characterized this transformation as regrettable. ${ }^{133}$ In Canada, women directors have also reported this sort of self-transformation, or shifting of behaviors to conform to stereotypically male norms. ${ }^{134}$ Further, female directors of Financial Post 500 companies have recounted experiences of social alienation that resulted in feelings of desolation and in reduced access to networks that would provide key professional relationships and information. Surveyed board members have expressed the feeling that male directors view them as mere tokens and, correspondingly, that they must "overperform" in order to gain legitimacy. ${ }^{135}$ In the United States, a survey of female inside directors of Fortune 1000 companies reveals that particular business cultures entrench exclusionary processes that marginalize and disempower women and thwart their full engagement. ${ }^{136}$ For the women studied, such

\footnotetext{
${ }^{128}$ Kanter herself did not explicitly use the term "critical mass."

129 Rosabeth Moss Kanter, Men and Women of the Corporation (New York: Basic Books, 1977) at 206-07 [Kanter, Men and Women]. See also Rosabeth Moss Kanter, "Some Effects of Proportions on Group Life: Skewed Sex Ratios and Responses to Token Women" (1977) 82:5 Am J Soc 965. In the field of political science, Drude Dahlerup's work on critical mass is considered particularly influential. See e.g. Drude Dahlerup, "From a Small to a Large Minority: Women in Scandinavian Politics" (1988) 11:4 Scandinavian Pol Stud 275.

${ }^{130}$ Kanter, Men and Women, supra note 129 at 207.

131 Ibid.

132 Judi Marshall, “Working at Senior Management and Board Levels: Some of the Issues for Women” (1995) 10:3 Women Mgmt Rev 21 at 23.

133 Ibid.

${ }^{134}$ Brad Long \& Elana Morris, “Beyond Corporate Board Representation: Understanding the Experience of Female Directors in Canada" (2008) 5 Workplace Rev 10 at 13.

135 Laura Jenner, Monica Dyer \& Lilly Whitham, "2007 Catalyst Census of Women Board Directors of the FP500: Voices from the Boardroom" (2008) at 31, online: Catalyst <http://www.catalyst.org/knowledge/2007-catalystcensus-women-board-directors-fp500-voices-boardroom>. For similar findings in other international studies, see e.g. McInerney-Lacombe, Bilimoria \& Salipante, supra note 108 at 133 ("An overarching theme emerging from the data was that board membership can be lonely and isolating for women.").

136 Deborah Dahlen Zelechowski \& Diana Bilimoria, "The Experience of Women Corporate Inside Directors on Boards of Fortune 1,000 Firms" (2003) 18:7 Women Mgmt Rev 376 at 379.
} 
Not a final version. Final version forthcoming in Challenging Boardroom Homogeneity: Corporate Law, Governance, and Diversity (Cambridge University Press, 2015)

processes included being shut out of significant meetings with clients and being micromanaged by the CEO while conducting performance assessments of lower-level colleagues. ${ }^{137}$

As others note, Kanter's original research focused on the relationship between low levels of representation and trying work environments; it did not assert that more balanced levels would yield different organizational outcomes. ${ }^{138}$ Subsequent studies utilizing the critical mass framework, however, do make this claim, ${ }^{139}$ suggesting that outlier groups will exert tangible influence only after achieving a certain degree of representation. When this occurs, their views and abilities may become more entrenched in the organization's deliberative processes-for example, as the individuals become more socially integrated and are thus increasingly relied upon. ${ }^{140}$

Thus, contemporary studies applying critical mass theory suggest that the "numbers game" can be an important factor in alleviating negative experiences and in facilitating women's and other groups' more robust and influential participation. In one empirical study of US boardrooms, the authors concluded that "having three or more women on a board can create a tipping point where women are no longer seen as outsiders and are able to influence the content and process of board discussions more substantially, with positive effects on corporate governance." ${ }^{141}$ An investigation of Israeli companies found higher levels of engagement by both male and female board members "when a critical mass of three women directors is in attendance." ${ }^{142}$

The merits of critical mass theory are vigorously debated in various social contexts. ${ }^{143}$ In Broome, Conley, and Krawiec's study, the authors "found only limited evidence that a critical mass of women affected board behavior in any substantive way," except when it came to industrial relationsrelated issues. ${ }^{144}$ In my study, after discussing the potential relationship between gender diversity and board decision making and governance, I asked participants whether, in their view, critical mass is a factor in realizing any diversity-related benefits. Overall, the majority of the sample indicated that critical mass was indeed a salient factor. ${ }^{145}$ This includes a small number of responses where the participant observed this to be the case, but suggested that some additional, accompanying quality was also necessary, namely that the women constituting the critical mass be actively engaged. Further, of those who responded positively, most felt that either two or two or more women were necessary to

137 Ibid.

138 Lissa Lamkin Broome, John M Conley \& Kimberly D Krawiec, “Does Critical Mass Matter? Views from the Boardroom" (2011) 34:4 Seattle UL Rev 1049 at 1052 [Broome, Conley \& Krawiec, "Does Critical Mass Matter?"]. 139 Ibid.

${ }^{140}$ Quinetta M Roberson \& Hyeon Jeong Park, “Examining the Link Between Diversity and Firm Performance: The Effects of Diversity Reputation and Leader Racial Diversity" (2007) 32:5 Group \& Org Mgmt 548 at 563-64.

${ }^{141}$ Kramer, Konrad \& Erkut, supra note 72 at 53. Also in the US context, see Heather Foust-Cummings, "Women on Corporate Boards of Directors: Best Practice Companies" in Vinnicombe et al, supra note 49, 210 at 214-15. For a study finding a positive association between critical mass and performance in German companies, see Jasmin Joecks, Kerstin Pull \& Karin Vetter, "Gender Diversity in the Boardroom and Firm Performance: What Exactly Constitutes a 'Critical Mass?'” (2013) 118:1 J Bus Ethics 61.

${ }^{142}$ Miriam Schwartz-Ziv, “Does the Gender of Directors Matter?” (2 December 2013) at 38, online: SSRN <http://papers.ssrn.com/sol3/papers.cfm?abstract id=1868033>.

${ }^{143}$ See Broome, Conley \& Krawiec, “Does Critical Mass Matter?”, supra note 138 at 1053-54 (surveying the literature).

144 Ibid at 1060.

${ }^{145}$ For a prior survey-based study of critical mass and Norwegian boards, related to innovation, see Mariateresa Torchia, Andrea Calabrò \& Morten Huse, "Women Directors on Corporate Boards: From Tokenism to Critical Mass" (2011) 102:2 J Bus Ethics 299. 
Not a final version. Final version forthcoming in Challenging Boardroom Homogeneity: Corporate Law, Governance, and Diversity (Cambridge University Press, 2015)

establish a critical mass. ${ }^{146}$ The following comments of a female director were particularly instructive in linking the quota law's required level of gender balance with the benefits of critical mass:

I think forty [percent] is perfect. ... And the reason why I say that is that my experience is that when you're the single one being a female on those boards, you're more [likely to] adopt to the way the board has always done or performed their meetings, . . . everything is like before, you more easily adopt to the culture already there. . . But when it's 40 percent, you actually make a change. ${ }^{147}$

In some cases, my critical mass-related exchanges with female participants led to discussions of whether the presence of more women on the board had made a difference to the interviewee at a personal level. This catalyzed some poignant reflections on the experience of navigating traditionally male-dominated environments. One respondent offered these thoughts:

I've been the only woman in very, very many situations, as I was early put into managerial positions. . . . So I've been used to being alone, so to speak. And I can deal with that, but it becomes lonely to be the only woman in a male setting. . . . [1]t's not a desirable position, really. And even if you disagree with other women, it just feels better. It gives a feeling of comfort and ease and you don't need to feel that [you must] be on your toes ... you know, say the right things or not say the right things, and that [that] may be ... used against you because you're a woman. ${ }^{148}$

This general theme of being a sole female director, or the sole female in other similar leadership contexts such as government or senior management, came up frequently during the interviews and is noted in social psychological literature to have negative effects on performance outcomes. ${ }^{149}$ Not surprisingly, the majority of respondents who broached this topic described the experience with reference to feelings of marginalization, expressing, for example, that: "it's hard to be the single skunk"; ${ }^{150}$ it's "lonely" to be the only woman; ${ }^{151}$ one feels "more at ease" when one is "not the only woman"; ${ }^{152}$ and that "[i]t's tough to be a loner" and it is "a little bit easier, even if you're high on courage," to have another woman on the board. ${ }^{153}$

Even the minority of female directors who indicated that being the lone woman was not a problem for them personally nonetheless conceded that it was "better,"154 "important," 155 "very

\footnotetext{
${ }^{146}$ When my respondents suggested that critical mass was relevant, I noted the number of women on the board that they felt was necessary to realize diversity-related benefits. In cases where interviewees indicated that being the sole female or outlier board member was not enough, but did not indicate a specific number that was advantageous, I coded the responses as "two or more," reflecting that one female director was insufficient.

147 Interviewee 8, Transcript, at 17.

148 Interviewee 19, Transcript, at 14.

${ }^{149}$ See e.g. Mischa Thompson \& Denise Sekaquaptewa, "When Being Different Is Detrimental: Solo Status and the Performance of Women and Racial Minorities" (2002) 2 Analyses Soc Issues \& Pub Pol'y 183 at 199 (“A growing body of laboratory and field research indicates that being the only member of one's race or gender in educational or work settings is more detrimental to the performance of women and racial minorities than Whites and males.").

${ }^{150}$ Interviewee 4, Transcript, at 7.

151 Interviewee 6, Transcript, at 14.

152 Interviewee 8, Transcript, at 28.

153 Interviewee 14, Transcript, at 10-11.

154 Interviewee 2, Transcript, at 9.

155 Interviewee 10, Transcript, at 14.
} 
Not a final version. Final version forthcoming in Challenging Boardroom Homogeneity: Corporate Law, Governance, and Diversity (Cambridge University Press, 2015)

nice,"156 or "quite nice"157 to have more than one woman on the board. Some male directors were also sympathetic, offering that "[i]t would be a disadvantage for one woman to come in as ... the first woman ever on that board and to be alone" because "she might find herself up against the old boys' network," 158 and that "it could be very tough to be the only" woman on a board. ${ }^{159}$ I followed up with a number of the female interviewees who indicated a preference for the presence of other women around the boardroom table and asked whether this preference was dependant on the other female(s) agreeing with them or sharing the same opinion. All directors who were asked this question answered that their preference for, or the benefits of, gender diversity on boards did not depend on the other female director(s) expressing concurrence with a substantive opinion. These results appear to be consistent with the "stereotype inoculation model" found in Dasgupta's social psychology work, suggesting that the presence of "ingroup members . . . in high-achievement settings . . function as 'social vaccines' who inoculate and strengthen fellow group members' self-concept."160

\section{(v) Compromised efficiency?}

The majority of my sample indicated that gender diversity has a positive effect on decision making and governance, which manifests itself through, for example, deeper probing into issues facing the firm, asking more challenging questions of management and of other board members, and producing more robust dialogue. But are there potential negative effects of diversity on the deliberative process? Prior research in fields such as organizational behavior and finance, for example, suggests that cognitive heterogeneity and the resulting give and take of differing positions can lead to increased social discordance ${ }^{161}$ and may compromise the efficiency of decision making. ${ }^{162}$

I delved more deeply into the potentially Janus-faced nature of gender-diverse boards, focusing on the possibility that the advantageous aspects of heterogeneity the sample perceived may actually have had the unintended result of slowing down decision making or making consensus more difficult to achieve. ${ }^{163}$ On this issue, while the ability to reach consensus did not appear to be a major hurdle, most participants conceded that gender-mixed boards can take more time to do so. My respondents did not, however, view this negatively. Of the directors who made this concession, the majority simultaneously indicated that any efficiency loss was nonetheless beneficial for their boards given the higher quality of the resulting decision. As one male director noted, "I think that's valuable. If you reach consensus in a few seconds, there hasn't been any discussion. . . . You haven't learned anything from that discussion." ${ }^{164}$ The rhetorical questions of a female director echoed this sentiment: "[W]hat's the

\footnotetext{
${ }^{156}$ Interviewee 13, Transcript, at 22.

${ }^{157}$ Interviewee 16, Transcript, at 17.

${ }^{158}$ Interviewee 18, Transcript, at 11.

${ }^{159}$ Interviewee 23, Transcript, at 11.

160 Nilanjana Dasgupta, "Ingroup Experts and Peers as Social Vaccines Who Inoculate the Self-Concept: The Stereotype Inoculation Model” (2011) 22:4 Psychol Inquiry 231 at 232.

${ }^{161}$ Tony L Simons \& Randall S Peterson, "Task Conflict and Relationship Conflict in Top Management Teams: The Pivotal Role of Intragroup Trust" (2000) 85:1 J Applied Psychol 102 at 103.

162 Ronald C Anderson et al, "The Economics of Director Heterogeneity" (Spring 2011) 40:1 Fin Mgmt 5 at 17 [emphasis added] ("Although a diverse pool of directors can bring multiple and varying insights to board deliberations, these same attributes arguably increase communication costs and protract decision-making processes.").

${ }^{163}$ Donald C Langevoort, "Commentary: Puzzles about Corporate Boards and Board Diversity" (2011) 89 NCL Rev 841 at 845 ("There are downsides to diversity because diverse teams are less likely to reach consensus, and take more time to do so if they do.").

${ }^{164}$ Interviewee 15, Transcript, at 5-6.
} 
Not a final version. Final version forthcoming in Challenging Boardroom Homogeneity: Corporate Law, Governance, and Diversity (Cambridge University Press, 2015)

success of a board meeting? Is it that it closes at a scheduled time? Or is it that you made a good decision?"165

Interestingly, another male director, while acknowledging the possibility of an increase in deliberation time, placed the onus for any such increase and the resulting inefficiencies squarely on the shoulders of management. In his view, women in the boardroom are asking more questions, probing deeper, and requesting more documentation. But any inefficiency lies in the fact that management is sometimes unprepared to meet these (reasonable) demands:

Interviewer: Does it take longer then, to achieve consensus?

Respondent: That would, I think, depend on how good the management of the companies are in providing the necessary documentation ... as part of the presentation of the various issues. I think ... if they are good at that, it doesn't necessarily . . . require more discussions or longer discussions. [So], I think I would say no. . . . [I]f [a decision] goes over more board meetings, it's not gender that causes that. ${ }^{166}$

This director, however, added that management is slowly "getting used to being better prepared" and drew an unambiguous connection between gender diversity and board monitoring: "[M]anagement is sort of getting to grips with the fact that young, well-educated women [are] coming on the board[s] [and] are asking for more information. . . . So I think, as far as improving quality of documentation for board decisions, I think that there's been an improvement and I believe that is coming from gender." ${ }^{167}$

Opening networks, redistributing power

Much of the narrative data I presented above center on the effects of gender-balanced corporate boards, as achieved through Norway's quota regime. They paint a portrait of the ways in which legally mandated diversification has affected boardroom cultural dynamics, decision making, and overall governance. The portrait consists of numerous, interrelated positive impacts. But the quota law has also arguably had broader social effects by redistributing power in Norwegian society. That important power dynamics are at stake is reflected in the fact that many firms did not comply when the quota was voluntary.

Female interviewees noted that some male directors were loath to "give away . . power"168 by surrendering their "privileged . . . leadership positions"169 to women and that males' positions on boards "were threatened" as a result of the quota law. ${ }^{170}$ One remarked that some male directors' negative reaction to the quota law was based on the reluctance to "giv[e] up something" and having to witness that thing "going to young women instead of [to] themselves." ${ }^{171}$ One male interviewee echoed these observations, discussing how male directors recognize the contribution of female directors to governance, "but not necessarily ... [at] the expense of their own participation."172 Further, some directors felt that low levels of female representation in certain industries are rooted in the male power

\footnotetext{
165 Interviewee 4, Transcript, at 8.

166 Interviewee 20, Transcript, at 5.

167 Ibid at 5-6.

168 Interviewee 3, Transcript, at 10.

169 Interviewee 14, Transcript, at 15.

170 Interviewee 3, Transcript, at 17.

171 Interviewee 14, Transcript, at 13.

172 Interviewee 20, Transcript, at 9.
} 
Not a final version. Final version forthcoming in Challenging Boardroom Homogeneity: Corporate Law, Governance, and Diversity (Cambridge University Press, 2015)

that would be lost in these particularly lucrative fields. One respondent, in discussing the extractive and financial sectors, remarked that these industries are home to "the really, really hard cash" and thus represent "the last border [that] will break." In her view, men working in these areas are especially likely to perceive women as "taking positions" and "claiming some of [their] power" and that "the higher the stakes ... the harder it is to get in!"173

At an operational level, the mandatory quota served to redistribute these positions of power in several ways. As I touched on above, when noting the attributes of independence and outsider status that women bring to the boardroom, many respondents discussed how the quota compelled boards and nominating committees to extend their searches for new directors beyond the usual, traditional spheres of comfort. Boards had no choice but to look outside of their existing networks and to search beyond candidates with CEO and C-suite experience or directly related industry experience. In the words of the interviewees, firms "have been forced to look in a . . . broader environment than . . . they traditionally do." ${ }^{174}$ The quota law "demands a wider search," ${ }^{175}$ which means engaging networks that firms are perhaps "not used to deal[ing] with"176 and expanding their "one-dimensional picture of what [a] board member should be," 177 instead of preserving the usual dynamic of "friends recruiting friends into the boardrooms." 178 Firms are now considering a "whole different corner than they ever did before" and opening up a "whole new set of ... relationships."179 In doing so, they have "expand[ed] the recruitment base" and effectively "doubl[ed] . . the talent pool they are picking from." 180

In supporting the mandatory quota, some respondents indicated that, without it, recruitment based on personal ties and similar backgrounds or characteristics would continue. These responses, along with the redistribution effects my interviewees noted, highlight the salience of implicit cognitive bias and closed social networks in blocking gender diversity, as I discussed in chapter 2. One director specifically cited this theme as a reason for endorsing quotas over disclosure strategies, opining that disclosure is too weak a measure to effectively break the pattern of in-group favoritism in recruitment: "[I]t's too tempting to ... give [a board position] to someone that understands you, that will not necessarily ask those difficult questions; someone that . . . is a little bit similar to you, and that you get an advantage from [by] putting there."

This theme emerged prominently in the interviews. A significant degree of the support for the quota law ultimately stemmed from the view that the law was necessary to diversify boards in a meaningful way-an outcome most respondents supported. In perhaps one of the most telling set of exchanges during my field work, I asked sample members if, in their view, the current levels of gender representation achieved under the quota law would remain intact if the state were to rescind the law. Only a thin minority felt that they would, while over two-thirds of the sample believed that the levels, overall, would decrease. Interviewees did not agree on the timing or magnitude of this hypothetical change. Some opined that the drop would be gradual, while others suspected that it would be instantaneous. Some predicted the decrease would be slight, while others thought it would be

\footnotetext{
${ }^{173}$ Interviewee 5, Transcript, at 9.

${ }^{174}$ Interviewee 3, Transcript, at 7.

${ }^{175}$ Interviewee 5, Transcript, at 5.

176 Interviewee 19, Transcript, at 19.

177 Interviewee 18, Transcript, at 17-18.

178 Interviewee 16, Transcript, at 8.

179 Interviewee 7, Transcript, at 16.

180 Interviewee 2, Transcript, at 6.

181 Interviewee 14, Transcript, at 15.
} 
Not a final version. Final version forthcoming in Challenging Boardroom Homogeneity: Corporate Law, Governance, and Diversity (Cambridge University Press, 2015)

significant. One participant said a decrease would occur in particular companies only. Despite this disagreement, however, one thing was clear: The most frequently cited factor in explaining why the levels would decrease was that of network-based barriers and in-group favoritism. One interviewee, for example, stated that "it's easier, more comfortable" and "quicker" for firms to pick a man for a board position. ${ }^{182}$ Another felt that owners can more easily relate to a person who "seems to have basically the same values or competence... and he's been doing something which is similar" and stated that "the network is still . . . heavily tilted male." ${ }^{183}$

The redistribution effect raises the question of whether affected directors might have mixed feelings about the law even if they see its benefits for boardroom operations. Even if diversification has positive effects on company governance, the question remains: Why are quotas an appropriate mechanism by which to achieve those benefits, especially given the intense controversy surrounding them? Put another way, even if participants have provided a convincing narrative of governance heterogeneity, why do they support (even if hesitantly) positive discrimination as a means of achieving it? For one male director, the various benefits he associated with diversification still did not justify the quota:

Interviewer: So we've had a really good discussion about both the positives and the negatives. ... [O]verall, do you support the use of quotas for increasing gender diversity on boards?

Respondent: No ... but that's more . . . a philosophical and political way of reasoning. Because ... I'm of the general opinion that you can't introduce a legal framework for everything you want to achieve in the society.

$\cdots$

Interviewer: What's been achieved so far, all of the benefits that we've just talked about, do you think they would have happened without the legal framework?

Respondent: No. No. No.

Interviewer: (laughing) So can you help me reconcile those two statements? ${ }^{184}$

This director, however, was in the minority. Most respondents thought that the quota law proved justified because of its efficiency in increasing levels of female representation on boards in a short period of time, and many additionally supported it because its mandate served the important objective of utilizing the entire talent pool available in Norwegian society. Again, some interviewees further noted that Norwegian firms did not heed the call to increase gender diversity (at least at any significant level) during the voluntary period; compliance had to be mandated.

(vii) The absence of stigma

In chapter 3, I noted that one of the major critiques of quotas is that they may stigmatize their beneficiaries. In the United Kingdom, for example, a recent House of Lords committee report recommended against pursuing quotas as a line of first resort because, among other things, the

\footnotetext{
182 Interviewee 19, Transcript, at 19.

183 Interviewee 20, Transcript, at 16.

${ }^{184}$ Interviewee 23, Transcript, at 12.
} 
Not a final version. Final version forthcoming in Challenging Boardroom Homogeneity: Corporate Law, Governance, and Diversity (Cambridge University Press, 2015)

committee felt that positive discrimination "would risk fostering the perception-though entirely incorrect-that women on boards were not there by merit." ${ }^{185}$ The committee reached this view after hearing conflicting evidence from witnesses. Some opined that quota-based measures are "patronizing or tokenistic, and risk . . . undermining the perception of women in senior positions." ${ }^{186}$ Others, however, expressed the view that, "rather than being patronizing . . . quotas provided the means to overcome structural inequalities in the labour market" ${ }^{187}$ and that "it was not . . . in the least patronising to take effective steps to address the current bias in favour of men." ${ }^{188}$ Similarly, in Canada, a leading voice of institutional investors conjectured in a brief submitted to a Senate committee that "[q]uotas can result in unintended consequences, not the least of which is the potential stigmatization of the female candidates they are designed to promote. ${ }^{189}$ This refrain has been echoed in various settings, including in a policy submission by a consortium of corporations to the Ontario Securities Commission (regarding the regulator's proposed disclosure model), ${ }^{190}$ an influential report by one of Canada's largest banks (which also described quotas as "the antithesis of merit"), ${ }^{191}$ and the Canadian press. ${ }^{192}$

Mindful of the frequent speculation in policy conversations that quota-based regimes may have a stigmatizing, isolating, and/or patronizing effect-a possibility many use to advocate against quotas-I asked participants questions designed to learn: (a) whether the beneficiaries of positive discrimination have been stigmatized or treated differently from male directors; and (b) whether those who serve on boards alongside these beneficiaries perceive them to be stigmatized in some way. What has it meant for women to "invade" the traditionally male space of corporate governance? After relative numerical parity was achieved, what were the consequences for intraboard power arrangements?

Some participants observed that critics of Norway's quota law predicted that it would stigmatize beneficiaries, mirroring international policy dialogues. One director confessed that the possibility of this sort of toxic repercussion was one of the reasons why she initially opposed the law. While she now supports the law (with reservations), she also reported having experienced stigmatizing treatment, especially from the press: "[T]hey tend to say, (mimicking) 'Oh well, you just got this [position], of course, because of the quotation law.'" ${ }^{193}$ Another female director recounted the following story about a female colleague's entry to the board of another firm:

Respondent: l'll tell you one story. There's a female lawyer . . . specializing in shipping. She's really very good. And ... she came into this new shipping company

\footnotetext{
185 House of Lords European Union Committee, "Women on Boards Report" (9 November 2012) at 27, online: UK Parliament <http://www.publications.parliament.uk/pa/ld201213/ldselect/ldeucom/58/58.pdf>.

186 Ibid at 22.

187 Ibid at 24.

188 Ibid at 25.

189 The Canadian Coalition for Good Governance, "Brief to Senate Committee on Banking, Trade and Commerce" (31 January 2011) at 4, online: <www.ccgg.ca/site/ccgg/assets/pdf/CCGG Brief re Bill S-206.pdf>.

190 Letter from Norton Rose Fulbright Canada LLP to the Ontario Securities Commission (26 September 2013 ) at 2 (alleging that "legislated quotas . . . could result in the stigmatization of women in corporations across the country").

${ }^{191}$ TD Economics, supra note 68 at 2 ("They [quotas] also risk stigmatizing qualified women on boards as 'tokens', which can undermine the cause being championed.").

192 Margaret Wente, “Janet Yellen Didn't Need a Quota", The Globe and Mail (6 February 2014), online: <http://www.theglobeandmail.com/globe-debate/janet-yellen-didnt-need-a-quota/article16724292/> ("TT]he soft tyranny of affirmative action drives me nuts. You wind up with tokenism or worse.").

193 Interviewee 13, Transcript, at 19.
} 
Not a final version. Final version forthcoming in Challenging Boardroom Homogeneity: Corporate Law, Governance, and Diversity (Cambridge University Press, 2015)

board. And the chairman looked at her ... and then he said, (mimicking) 'Oh, and then I see we have ... Pippi Longstocking on the board.' ... Now her hair is red and . . . you know, it was like, she ... [says,] (mimicking) 'Fuck you.' - Sorry.

Interviewer: No, ... it's okay.

Respondent: ... [S]he's a tough woman, but really, you know, it was not a good start. ... And he may not have meant it very badly, but, you know . . ${ }^{194}$

Overall, however, only a small minority felt that these sorts of effects had actually come to pass and were a salient issue, or at least speculated that stigma had resulted. And even amongst this minority, not all respondents would characterize the differential treatment as occurring along gendered lines. One participant, for example, felt that any newcomer to an organization will be subjected to enhanced scrutiny and to the expectation that he or she "earn [his/her] spurs." 195 Contrary to critics' initial predictions, the majority of the sample (slightly more than 85 percent): (a) did not observe stigmatizing or isolating effects or differential treatment; (b) observed such effects, but in only a very limited number of cases; (c) observed such effects, but did not think them salient or felt that they could be managed; or (d) observed such effects, but for only a limited period of time, immediately after the quota law was passed. This suggests that the benefits of the quota law have outweighed any stigmatizing costs, to the extent that these costs have materialized.

Interestingly, one male respondent suggested a gendered dimension to the stigmatization argument itself. In his view, men strategically employ it to thwart women's progress, leading him to characterize it as "a hopeless ... male argument." ${ }^{196}$ Another male respondent expressed the view that the quota law had "normalized" gender diversity on boards such that it is now viewed as a "quality stamp" of firms and part of how "a proper company should function." ${ }^{197}$ This interviewee suggested that the risk of stigmatization was a live issue only in the period immediately following the quota's implementation, but not after it became internalized:

[I]n the first year of the quota law, definitely it was looked upon . . . in a [certain] way and I also think that even very qualified female members hesitated to take on board positions because they were afraid of being stigmatized. But that has definitely changed. ... [Now] I think you'll find that [women] are just as qualified, if not better, than most of their male colleagues, actually. ${ }^{198}$

Given that respondents had offered vivid accounts of insular recruitment processes and masculinist boardroom dynamics that predated the quota, one might think that women would encounter resistance and stigma after taking their seats at the table. And yet, comments such as these were not atypical: "I think that [stigmatization] was predicted, but I don't think it has happened. I truly believe that all board members are perceived and treated as professionals." ${ }^{199}$ Perhaps the expressions of sexism were reserved for outside the boardroom, in separate social spaces? Perhaps these

\footnotetext{
${ }^{194}$ Interviewee 11, Transcript, at 25.

${ }^{195}$ Interviewee 18, Transcript, at 20.

${ }^{196}$ Interviewee 15, Transcript, at 19.

${ }^{197}$ Interviewee 22, Transcript, at 11.

198 Ibid at 16-17.

${ }^{199}$ Interviewee 4, Transcript, at 19.
} 
Not a final version. Final version forthcoming in Challenging Boardroom Homogeneity: Corporate Law, Governance, and Diversity (Cambridge University Press, 2015)

expressions took the form of everyday microaggressions that were less conspicuous and in some cases were not registered or taken seriously if they arose from ignorance or lacked malevolent intent? My respondents suggested different explanations. Some, for example, explained the absence of stigma as a function of critical mass. By mandating gender balance and foreclosing any possibility of tokenism, the quota law made marginalization difficult, if not impossible. As one female participant remarked:

When you first enter that room, you're treated as a board member, regardless of how you entered the room.... At least that's my experience. ... And all the other females I've talked to say exactly the same thing. Because when you're representing 40 percent in there, you can't stigmatize 40 percent of the board. . . . [Y]ou could have stigmatized one person, or 15 percent. . . But you can't stigmatize 40 percent. ${ }^{200}$

It is clear that female directors in the sample generally did not speak about the quota law in a manner suggesting that it has had stigmatizing effects. ${ }^{201}$ The majority of female participants reported that they felt comfortable on the boards on which they sat, identified and discussed what they perceived to be their main contributions to their boards, and confirmed the feeling that their boards recognized or appreciated their contributions. These results are consistent with the conclusions of previous survey-based studies on Norwegian female directors. Elstad and Ladegard, for example, found that women directors "perceive contributions of high levels of ... influence and information sharing ... and low levels of . . . self-censorship," results that "are not in accordance with the predictions of tokenism theory, but are more aligned with critical mass arguments." ${ }^{202}$ Mathisen, Ogaard, and Marnburg further found evidence "that female directors are welcomed into boardrooms, not perceived as out-groups, and [boards] are able to benefit from the female directors' experience and skills."203

Rather than employing a discourse of stigma or tokenism, the majority of my sample characterized the quota as a vehicle that-in their lives-has facilitated access to the upper echelons of the corporation. These interviewees used various terms to describe this facilitation. One remarked that, post quota, she has been approached more frequently to join public company boards and that she is "sure it helped [her] to get into the ... set of candidates" being considered. ${ }^{204}$ Others described how the law has "opened a fabulous opportunity" ${ }^{205}$ or has constituted "a huge opportunity."

Other interviewees were even more explicit. One commented, "I have no doubt that I would not have had those [board] positions without the quota law . . . and that has been . . . understood. Not directly communicated, but sort of understood. . . . And, frankly, I don't mind." 207 Similarly, another discussed how she had not held a board position until the quota law passed, and thus admitted that she

\footnotetext{
200 Interviewee 8, Transcript, at 27.

201 See also Ruth Sealy, Elena Doldor \& Susan Vinnicombe, "Increasing Diversity on Public and Private Sector Boards: Part 2 - What is Being Done to Improve Diversity on Boards and How Effective is This?" (November 2009) at 43, online: Cranfield University <https://dspace.lib.cranfield.ac.uk/handle/1826/5267> (discussing the stigma concern and stating "few would argue today that it [the quota] has done women's careers any damage").

202 Beate Elstad \& Gro Ladegard, “Women on Corporate Boards: Key Influencers or Tokens?" (2012) 16:4 J Mgmt \& Governance 595 at 610. See also Gro Ladegard, "Legitimacy, Inclusion and Influence: Investigating Women Directors' Board Experiences" in Machold et al, supra note 25, 147.

${ }^{203}$ Gro Ellen Mathisen, Torvald Ogaard \& Einar Marnburg, "Women in the Boardroom: How Do Female Directors of Corporate Boards Perceive Boardroom Dynamics?" (2013) 116:1 J Bus Ethics 87 at 87.

${ }^{204}$ Interviewee 2, Transcript, at 21.

${ }^{205}$ Interviewee 4, Transcript, at 9.

206 Interviewee 10, Transcript, at 9.

${ }^{207}$ Interviewee 5, Transcript, at 2.
} 
Not a final version. Final version forthcoming in Challenging Boardroom Homogeneity: Corporate Law, Governance, and Diversity (Cambridge University Press, 2015)

got an "opportunity because of the law," 208 given that she did not think she "would have been on the boards if it hadn't been for this quota law." ${ }^{209}$ I should note that both of these women were unquestionably well qualified-one was a law firm partner with an impressive business law practice, and the other had extensive prequota industry management experience. Interestingly, another participant noted that the quota law afforded her access to a board of a company in a traditionally male-dominated industry: "[T]he maritime construction firm, I would have never ever entered into that industry or . . . been deemed suitable for . . . the board [of] such an industry, without the quota law." ${ }^{210}$ Another remarked that a particular board "probably wouldn't have even known about" her if not for the quota. ${ }^{211}$ This M.B.A. graduate had reached the partnership level at her firm and possessed managerial, consulting, and financial analyst experience.

\section{Conclusion}

Overall, the dynamics brought to light in these interviews suggest that Norway's quota law, as an instrument of economic governance, has had a profound effect on Norwegian companies. It has affected the social fabric and decision making culture of the boardroom, transformed overall firm governance, and shifted the landscape of existing gender-related power arrangements. That said, the lived reality of the quota law also gives rise to a number of interesting and difficult questions for future research and of particular relevance to other countries contemplating the adoption of a quota regime. These questions include: whether quota laws essentialize gender; whether the benefits of outsider status will disappear as women gradually assimilate onto boards and into the networks of male directors; whether quotas have a negative relationship with firm financial performance; whether boardroom diversity will enhance diversity in the management suite; whether quota regimes can be successful in countries with socio-political cultures that are different from that of Norway; whether the benefits of diversity are tied to particular features of corporate governance cultures; and whether publicly traded firms will attempt to avoid quota requirements by becoming private. I turn to these questions and the surrounding issues in chapter 5.

\footnotetext{
208 Interviewee 16, Transcript, at 4.

${ }^{209}$ Ibid at 18-19.

${ }^{210}$ Interviewee 8, Transcript, at 24.

${ }^{211}$ Interviewee 7, Transcript, at 16.
} 